University of Pennsylvania Carey Law School

Penn Law: Legal Scholarship Repository

Faculty Scholarship at Penn Law

1998

\title{
Objectivist vs. Subjectivist Views of Criminality: A Study in the Role of Social Science in Criminal Law Theory
}

\author{
Paul H. Robinson \\ University of Pennsylvania Carey Law School \\ John M. Darley \\ Princeton University-Department of Psychology
}

Follow this and additional works at: https://scholarship.law.upenn.edu/faculty_scholarship

Part of the Criminal Law Commons, Criminology Commons, Law and Psychology Commons, Law and

Society Commons, Law Enforcement and Corrections Commons, Public Law and Legal Theory Commons, Social Control, Law, Crime, and Deviance Commons, Social Psychology Commons, and the Social

Psychology and Interaction Commons

\section{Repository Citation}

Robinson, Paul H. and Darley, John M., "Objectivist vs. Subjectivist Views of Criminality: A Study in the Role of Social Science in Criminal Law Theory" (1998). Faculty Scholarship at Penn Law. 1525. https://scholarship.law.upenn.edu/faculty_scholarship/1525

This Article is brought to you for free and open access by Penn Law: Legal Scholarship Repository. It has been accepted for inclusion in Faculty Scholarship at Penn Law by an authorized administrator of Penn Law: Legal Scholarship Repository. For more information, please contact PennlawIR@law.upenn.edu. 


\title{
Objectivist Versus Subjectivist Views of Criminality: \\ A Study in the Role of Social Science in Criminal Law Theory
}

\author{
PAUL H. ROBINSON and JOHN M. DARLEY*
}

\begin{abstract}
The authors use social science methodology to determine whether a doctrinal shift-from an objectivist view of criminality in the common law to a subjectivist view in modern criminal codes-is consistent with lay intuitions of the principles of justice. Commentators have suggested that lay perceptions of criminality have shifted in a way reflected in the doctrinal change, but the study results suggest a more nuanced conclusion: that the modern lay view agrees with the subjectivist view of modern codes in defining the minimum requirements of criminality, but prefers the common law's objectivist view of grading the punishment deserved. The authors argue that there is practical value in having criminal law track shared community intuitions of the proper rules for assigning liability and punishment. For that reason, the study results support the often criticized subjectivist view of modern codes in setting the minimum requirements of liability, but disapprove of the modern codes' shift away from the common law's objectivist view of grading.
\end{abstract}

A central goal of criminal law theory is to understand why criminal law rules develop and exist as they do. That understanding allows us better to criticize or support the rules, to determine whether the rules serve their intended purposes, and to debate the wisdom of those purposes openly. We argue in this article that social science, properly used, can be an important resource for criminal law theorists, in both testing and suggesting explanatory theories for criminal law. We also show how it can provide essential data for the construction and application of theories of criminal law.

The most beckoning explanatory puzzle in criminal law theory concerns the variety of rule changes between the common law and modern criminal codes. Of central importance are those that concern the central questions of the role of culpable state of mind and of harm in assessing liability and punishment. Code commentaries and legislative histories often give explanations for specific

* Paul H. Robinson is Professor of Law at Northwestern University. John M. Darley is the Dorman T. Warren Professor of Psychology at Princeton University. Professor Robinson wishes to acknowledge the support of the Stanford Clinton, Sr., Research Professorship, and the contributions of participants at a faculty workshop at Northwestern University School of Law. 
rule changes, some explanations being more enlightening than others. What criminal law theorists have sought is, first, the identification of a discernible pattern in the changes, and, second, an explanation for that pattern of change. Such an understanding can help us to refine modern rules and their application, as well as to stimulate debate on the propriety of the shift from the common law rules. It is on this puzzle that we bring to bear the investigative tools of research psychology. As the reader will see, those tools advance the inquiry in ways that criminal law theorists on their own could not.

Part 1 of the article offers a traditional theoretical analysis to suggest that there is a pattern in the rule changes between common law and modern codes. Drawing from the existing scholarly literature, it also describes one theory for the doctrinal shifts, what is called a shift from the 'traditionalists' view to that of the 'modernists' view. We also offer our own variation on this theory of doctrinal shift, a shift from what we call an objectivist view of criminality to a subjectivist view. Social science, we argue, can test theories like these. The article sets out a series of specific testable empirical questions that are central to the theoretical debate.

Part 2 describes the social science tools to be used in the testing. In this case, the primary tool is termed 'scenario research' and the reasons for using it are given. Part 3 applies the social science test instruments described in Part 2 to the legal theories developed in Part 1, in order to identify those test results that indicate that a test subject is taking an objectivist view of criminality and those that indicate a test subject is taking a subjectivist view. Part 4 reports the results of the tests and their implications, and answers the questions presented in Part 1. A concluding section offers general observations about the analytic exercise and its implication for criminal law reform and future social science research.

\section{Theories for a Pattern of Criminalization Differences Between Common Law and Modern Codes}

Many changes from common law doctrine to modern criminal codes are easily explainable as responses to changing conditions. As societal interdependencies grew, so did the variety of ways in which a person could harm society, its institutions, or other persons. Thus, new offences were created and old offences altered to take account of new harms. For example, most modern criminal codes contain white collar business crimes and special organized crime offences that did not exist at common law. Other modern criminal code changes are simply attempts to make criminal law more clear and more comprehensive, as the legality principle demands. Thus, modern codes typically define commonly used terms, limit the number of culpability levels used in the definition of offences, carefully defining each, and codify a comprehensive set of defences. The changes of greatest interest to criminal law theorists, however, have been those that suggest some kind of paradigm shift in defining the core of what constitutes 
'criminality', that is, changes that suggest that the foundational substance of the law has changed not just its form or application.

\section{A. Common Law versus Modern Codes: Doctrinal Shifts}

Consider the different views of criminalization that might be suggested by the following comparisons. The common law recognized an unconvictable perpetrator defence to complicity, under which the accomplice escaped liability if the perpetrator was unconvictable (because the perpetrator lacked the culpability required for the offence, for example). ${ }^{1}$ Modern codes typically reject such an unconvictable perpetrator defence, arguing that an accomplice's liability ought to depend upon what the accomplice did and the accomplice's state of mind, and that the perpetrator's defence ought not to alter the accomplice's liability. ${ }^{2}$

In the context of conspiracy, the common law defined the agreement requirement as two or more persons agreeing. Not only did the defendant have to agree with another, the other person genuinely had to agree back. ${ }^{3}$ Agreeing with an undercover agent, for example, did not constitute an adequate agreement for conspiracy liability. Modern codes typically drop this 'bilateral' agreement requirement for conspiracy, and simply require that the actor have agreed with another, termed a 'unilateral' agreement requirement. ${ }^{4}$

In the context of attempts, the common law permitted a defence if an actor attempted an offence that, unknown to the actor, was impossible to complete

\footnotetext{
1 In Regina v Richards [1974] 1 QB 776 (CA, Crim. Div.), defendant wife had hired defendant perpetrators to beat her husband 'bad enough to put him in the hospital for a month'. Ibid at 778. After beating the husband, but failing to inflict the type of serious bodily harm the wife had requested, the perpetrators were convicted of unlawful wounding; the wife as accomplice was, in turn, convicted of wounding with intent to do grievous bodily harm. On appeal, her conviction was overturned because the only offence committed by the perpetrators was unlawful wounding, and an accomplice, held the court, "cannot be guilty of a graver offence than that in fact which was committed'. Ibid at $\mathbf{7 8 0}$.

${ }^{2}$ See, eg Model Penal Code s. 2.06(7):

An accomplice may be convicted on proof of the commission of the offence and of his complicity therein, though the person claimed to have committed the offence has not be prosecuted or convicted or has been convicted of a different offence or degree of offence or has an immunity to prosecution or conviction or has been acquitted.

See also Regina v Cogan E' Leak [1976] 1 QB 217 (CA, Crim. Div.), in which Leak induced Cogan to rape his (Leak's) wife. Perpetrator Cogan received a defence for his mistake as to the wife's lack of consent. Leak argued that he could not be convicted of complicity in the rape as Cogan had not been found guilty due to his mistake. In rejecting this rationale, the court noted that 'the wife had been raped. Cogan had sexual intercourse with her without her consent. The fact that Cogan was innocent of rape because he believed that she was consenting does not affect the position that she was raped.' Ibid at 223.

${ }^{3}$ See, eg Archbold v State 397 NE2d 1071 (Ind App 1979), in which the court held that '[t]he offence of conspiracy does not occur, a crime is not committed, until two or more persons form the intent to commit a felony. The joint intent is the proscribed conduct.' Ibid at 1073 (emphasis in original).

${ }^{4}$ See, eg Model Penal Code s. 5.03(1)(a) and(b).

The unilateral approach makes it immaterial to the guilt of a conspirator whose culpability has been established that the person or all of the persons with whom he conspired have not been or cannot be convicted. Traditional law has frequently held otherwise, reasoning from the definition of conspiracy as an agreement between two or more persons that there must be at least two guilty conspirators or none.
}

Model Penal Code s. 5.03 comment 398-402 (1985). See also People v Schwimmer 66 AD2d 91,411 NYS2d 922 (1978), aff'd, 47 NY2d 1004, 420 NYS2d 218, 394 NE2d 288 (1979) (the court held that since the legislature had adopted a unilateral agreement requirement, the defendant's agreement alone was sufficient to support conspiracy to steal diamonds, although the co-conspirators were undercover police officers). 
under the circumstances as they actually existed. Thus, the actor who purchased goods believing them to be stolen, could not be held liable for an attempt to receive stolen goods where the goods purchased were not, in fact, stolen. ${ }^{5}$ Modern codes, in contrast, reject an impossibility defence to all forms of inchoate liability. An actor's liability is to be determined from the point of view of the actor, under the circumstances as the actor believed them to be. ${ }^{6}$ If the actor believes that the goods are stolen, he can be held liable for an attempt to purchase stolen goods.

Also in the context of attempts, the common law adopted a variety of tests for determining whether an actor's conduct had moved from mere preparation to criminal attempt. The tests had in common their focus on how close the actor had come (his or her 'proximity') to completing the offence. ${ }^{7}$ Modern codes, following the Model Penal Code, look instead at how far the actor has gone from the start of the offence conduct. Once a 'substantial step' is taken, the actor has shown a willingness to act upon the actor's intention and, therefore, the actor's conduct is deemed adequate for a criminal attempt. ${ }^{8}$ Asking a secretary to type a letter that is the first of several steps in an elaborate fraud scheme, for example, would not constitute an attempt at common law, but could constitute a 'substantial step' sufficient for liability under modern codes.

One may note from these examples that the common law is consistent in imposing liability only in the instance where there actually (objectively) exists the danger of the offence harm or evil: by requiring an attempt possible of completion and, in the context of conspiracy, a true agreement between two conspirators, for instance. One might term this an objectivist view of criminality, which sees the gravamen of an offence as its objective harm or evil. It focuses upon whether the actor's conduct came close to bringing about the harm or evil of the substantive offence. Where the potential for the harm or evil exists only in the actor's mind, as is the case in impossible attempts, liability is inappropriate, hence the common law rule giving a defence for instances of legal impossibility.

Modern codes, in contrast, are willing to impose liability when the actor believes that he or she is committing or participating in a criminal offence. Under what might be called this subjectivist view of criminality, the focus is not on the harm or evil of the offence but upon the actor's subjective culpability in attempting to bring it about. Coming close to a substantive harm or evil is not required. The question is whether the actor has gone far enough to demonstrate that his or her intention is fully formed and resolute, hence the requirement of a

\footnotetext{
${ }^{5}$ See, eg People v Yaffe 185 NY 497, 78 NE 169 (1906), in which impossibility was held to be a defence to the receipt of stolen property where the goods had been 'wholly within [the owners'] control [at the time of sale] and [were] offered to the defendant by their authority'. Ibid at $499,78 \mathrm{NE}$ at 169.

See, eg Model Penal Code s. 5.01(1)(a).

7 The common law proximity tests include the most-often encountered 'dangerous proximity test', which requires a consideration of (1) the gravity of the offence intended, (2) the nearness of the act to completion of the crime, and (3) the probability that the conduct will result in the offence intended. See, eg Commonwealth v Peaslee 177 Mass 267, 59 NE 55 (1901) ('a mere collection and preparation of materials in a room for the purpose of setting fire to them, unaccompanied by any present intent to set the fire, would be too remote', ibid at 273,59 $\mathrm{NE}$ at 57).

${ }^{8}$ See, eg Model Penal Code s. $5.01(1)(c)$.
} 
'substantial step.' Similarly, while the actor's attempt may be impossible, it nonetheless may be adequate to show the actor's willingness to commit the offence.

The same common law-modern code conflict, between an objectivist and subjectivist view of criminality, can be seen in determining the importance that attaches to the close risk or actual occurrence of the offence. A logical extension of the subjectivist view of criminality suggests that there ought to be little or no significance given to whether the harm or evil of an offence actually occurs. If the primary focus of liability is the actor's subjective culpability, the important facts are what the actor has done in furtherance and as expression of that culpability (and the level of the actor's culpable state of mind at the time of the offence). Whether the harm or evil intended or risked actually occurs does not alter the actor's subjective culpability.

The objectivist view, in contrast, would insist on greater punishment where the harm or evil occurs, for it is the gravamen of the offence. While the objectivist might be persuaded to impose liability on the actor who comes close to bringing about the harm or evil, it seems clear that the objectivist would think that still greater liability is due where the harm or evil in fact occurs.

Thus the subjectivist-objectivist perspectives generate important differences in the criminal rules governing grading of offences. As it did with regard to minimum requirements for liability, the Model Penal Code generally takes a subjectivist view of criminality in grading. With a few exceptions, the Code's view is that the actual occurrence of a harm and evil ought not be significant. The actor's liability ought to depend only on the actor's culpable state of mind manifested in conduct. The most important provision implementing this view with respect to grading is Model Penal Code s. 5.05(1), which grades inchoate offences as follows:

Except as otherwise provided in this Section, attempt, solicitation and conspiracy are crimes of the same grade and degree as the most serious offence which is attempted or solicited or is an object of the conspiracy. An attempt, solicitation or conspiracy to commit a [capital crime or a] felony of the first degree is a felony of the second degree. ${ }^{9}$

Thus, except for attempted murder and attempted aggravated rape, all other attempts, for example, attempted arson, attempted sexual assault, are graded the same as the completed offence. The traditional view, reflected in the objectivist common law, was to punish the inchoate offence less than the completed offence. ${ }^{10}$

Similarly reflecting the Model Penal Code's subjectivist grading philosophy is the Code's complicity provision, which treats unsuccessful attempts to aid a

\footnotetext{
${ }^{9}$ Model Penal Code s. 5.05(1). Note that, while the Model Penal Code drafters adopt a subjective view of grading in the first sentence of this provision, they seem unwilling to take that view to its logical conclusion. In the last sentence, they make clear that attempted murder will get a reduction in grade from murder under the same circumstances.

${ }^{10}$ See, eg 2 James Fitzjames Stephens, A History of the Criminal Law of England (1883) at 224 (attempt to commit any felony was misdemeanour).
} 
perpetrator as complicity, for which full substantive liability is imposed. ${ }^{11}$ The Code's provision holds an actor as an accomplice if he 'aids or agrees or attempts to aid' in the commission of an offence. ${ }^{12}$ Thus, an unfulfilled agreement or unsuccessful attempt to assist or encourage is graded the same as the substantive offence. The actor who agrees to stand watch for a perpetrator bent on arson is liable for arson even if he gets the date confused and does not show up. In other words, inchoate complicity is punished not as inchoate liability but as full substantive liability. At common law, an unsuccessful attempt to aid would not constitute complicity in the substantive offence. ${ }^{13}$

\section{B. A Theory for the Doctrinal Shifts: Objectivist versus Subjectivist Views of Criminality}

To oversimplify, the distinction between what we have called an 'objectivist' and a 'subjectivist' view of criminality might be stated this way: The objectivist view maintains that the occurrence of the harm or evil defined by the offence is highly relevant; the subjectivist view maintains that such harm or evil is irrelevant; only the actor's culpable state of mind regarding the occurrence of the harm or evil is important. ${ }^{14}$

The labels tend to overstate a rather subtle distinction. The 'objectivist' or 'harmful consequences' view is not so objective as to require that the harm or evil of the offence actually occur in order to impose liability. The objectivist imposes liability for inchoate conduct, as, for example, when the actor comes close to bringing about a real offence harm or evil. ${ }^{15}$ The 'subjectivist' view, in turn, is not so subjective as to only require a culpable state of mind. An intention alone is insufficient for liability; some act is required to prove the actor's willingness to act upon, to externalize, his or her subjective culpability. ${ }^{16}$ And, while the occurrence of the harm or evil may not be important to the subjectivist, the nature of the harm or evil intended or risked is important to determine the degree of the actor's culpability. Intending to cause death is more serious than intending to rob someone.

11 See Model Penal Code s. 2.06(1), (2), (3)(a)(ii).

12 Model Penal Code s. 2.06(3)(a)(ii) (emphasis added).

13 Stephens, above $\mathrm{n} 10$ at $234-7$.

${ }^{14}$ Other writers have observed a similar distinction, although they would not necessarily characterize it as we do here. See, eg Lawrence Crocker, 'Justice in Criminal Liability: Decriminalizing Harmless Attempts' 53 Ohio St L Rev 1057 (1992) (comparing 'subjective' and 'objective' 'theories of criminal liability'); George P. Fletcher, Rethinking Criminal Law (1978) at 135-44, 389, 472-83 (referring to three 'patterns of liability': 'subjective', 'harmful consequences', and 'manifest').

${ }^{15}$ Generally, a 'harm' or a 'harmful result' is used in this article to refer to a tangible or intangible consequence of conduct, such as those consequences described in the result elements of offence definitions. 'Evil' conduct is used to refer to conduct that is objectionable and prohibited for its own sake rather than because it brings about a prohibited harmful consequence. Taken together, the 'harm and evil' of crimes is meant to include all prohibitions of the criminal law. The phrase 'harm and evil' is sometimes used in this article as shorthand for 'the occurrence of harm and evil',

${ }^{16}$ For further discussion of this function of the act requirement, see Paul H. Robinson, 'Should the Criminal Law Abandon the Actus Reus-Mens Rea Distinction?' in S. Shute, J. Gardner and J. Horder (eds), Criminal Law: Acrion, Value and Structure (Oxford, 1993). 
At least one writer has noted a similar distinction between the common law and modern codes and labeled the opposing views as 'traditionalist' and 'modernist'. ${ }^{17}$ Common law is said to reflect the objectivist view of the 'traditionalists', where the gravamen of an offence is its resulting harm or evil. The 'modernist' subjectivist view of criminality, in contrast, focuses upon the actor's culpable state of mind towards bringing about the offence harm or evil, without regard for whether the harm or evil actually occurs. George Fletcher explains:

The traditionalists root their case in the way we feel about crime and suffering. Modernists hold to arguments of rational and meaningful punishment. Despite what we might feel, the modernist insists, reason demands that we limit the criminal law to those factors that are within the control of the actor. The occurrence of harm is beyond his control and therefore ought not to have weight in the definition of crime and fitting punishment. The tension between these conflicting schools infects virtually all of our decisions in designing a system of crime and punishment. ${ }^{18}$

Recall the comparison of common law and modern code rules relating to minimum requirements. Each of these common law rules reflects a 'traditionalist' common law consistent in imposing liability only where an offence harm or evil or a credible danger of one actually exists. Completion of an attempt must be possible and must almost materialize; a conspiracy must be a true agreement between two actual conspirators; an accomplice must actually assist a real perpetrator. Where the potential for the harm or evil exists only in the actor's mind or is remote or speculative, traditionalists view the assignment of liability as inappropriate.

The subjective 'modernist' view focuses upon the actor's intention to bring about the offence harm or evil. An actor need not come close to a substantive harm or evil of the offence; he need only engage in some conduct, a 'substantial step', toward that end, to demonstrate his willingness to act upon his intention. Completion of an attempt need not be possible, provided that the actor thinks it is possible. The co-conspirator need not actually agree with the actor, provided that the actor thinks he does. The perpetrator need not actually commit an offence, provided that the accomplice thinks that he will.

\section{An Alternative Theory of Current Law's View of Criminality}

As Fletcher conceives of it, a person is either a 'traditionalist' or a 'modernist'. One either thinks that the occurrence of harm or evil is important to criminal liability, as the common law makers apparently did, or one thinks that it is not, as modern code drafters apparently think. While we agree that the distinction is valuable - what we call an objectivist versus a subjectivist view of criminality-we think that Fletcher's characterization of it is unnecessarily dichotomous. His traditionalist-modernist distinction is misleading because it incorrectly suggests that one must be either an objectivist or a subjectivist on all issues. In fact, we

\footnotetext{
${ }_{18}^{17}$ George P. Fletcher, A Crime of Self Defence: Bemhard Goetz and the Law on Trial (1988) at 64.
}

18 Ibid at 64 
will argue, it is possible to be a subjectivist on some issues but an objectivist on others. Specifically, we will argue that it would be logically coherent to advocate a subjectivist view of the minimum requirements of liability but simultaneously to take an objectivist view of grading.

If fact, we suggest that this is what ordinary people do. Thus, we carry out this argument about legal doctrines in what is an unusual way. We empirically investigate the liability assignment rules held by ordinary people in the community. We claim that, from the community's view of liability and punishment, the common law's objectivist view was too demanding in setting the minimum requirements of liability, as in defining inchoate offences. At the same time, subjectivist modern codes miss the mark when they take a subjectivist view in grading, as in ignoring the significance of resulting harm and evil. If we can demonstrate this, we certainly will have demonstrated that the distinction we propose is an important one to make.

\section{Testable Empirical Issues}

If this were a criminal law theory paper, this is where the analysis would end or at least would shift to a variety of forms of speculation. But the disagreements here are to some extent disagreements about how people think, essentially empirical claims. With the help of social science, we can collect and analyse data that may sketch real answers.

The discussion raises these testable empirical issues:

(1) Do people take an objectivist view, as the common law did, on both grading and minimum requirements issues, or do they prefer a subjectivist view, as modern criminal codes seem to? That is, are people of today Fletcher's 'traditionalists' or, as Fletcher would seem to predict by his labeling, 'modernists'?

(2) Are people consistent in the view they take? That is, do they stick to an objectivist view, or a subjectivist view, in a variety of situations? Or do they switch back and forth in a way that suggests that they cannot properly be characterized as taking either view?

(3) If people are not consistently 'traditionalists' or 'modernists,' as Fletcher predicts, is there nonetheless a discernible pattern in their use of an objectivist or a subjectivist view? Do people take a subjectivist view in judging the minimum requirements for liability and an objectivist view in grading, as we hypothesize? Or does the pattern follow a different principle? Or, is there no underlying pattern to peoples' liability preferences, as some writers would seem to expect? ${ }^{19}$ The next section describes how these empirical questions can be answered.

\footnotetext{
${ }^{19}$ Some writers have suggested that criminal law has few underlying patterns. See, eg Stephen Schulhofer, 'Book Review' 68 Cal L Rev 181 (1980) (reviewing George Fletcher's Rethinking Criminal Law).
} 


\section{Tools for Testing the Criminal Law Theories: Social Psychology Scenario Research}

\section{A. Scenarios and Measures}

There are a number of methods that can be used to probe lay judgments about complex issues, and the one we chose to use in this study was the 'scenario or vignette method'. Subjects are presented with a short description of a person's conduct, and are asked whether and, if so, how much liability and punishment the actor should receive for the conduct. Subjects are next given another scenario, and assess liability and punishment for that actor, then another scenario, and so on. The scenarios are varied by the researchers in ways driven by the theories being tested, and the researcher examines the differences between the liabilities assigned to each scenario.

Rather than having the subjects assign ratings to what can quite quickly become a large number of differing scenarios, why not just ask the subjects whether they think a subjectivist or an objectivist view of criminality is appropriate for the legal issues we are concerned with? Because psychologists have discovered that subjects often do not have mental access to the principles and processes they use to make decisions, and thus cannot accurately articulate those principles. Instead, researchers present subjects with various cases to judge, and infer their judging principles from the resulting patterning of responses between the different cases

This is what we did in the present research. We presented subjects with cases to judge in the form of short scenario descriptions of potentially criminal actions. Because the focus of our research was on contrasting various versions of the subjectivist and objectivist approaches to liability assignments, we designed the variations in our scenarios to reflect those different approaches. Generally, two cases differed in a way that would 'make a difference' to, for instance, a person with an objectivist view but not to a person with a subjectivist view. 'Make a difference' here means that the two cases would generate different liability judgments if the subject took one view of criminality, but not if he or she took the other view.

One way of summarizing the implications of the various aspects of the research design is to say that we conducted an experiment designed to determine whether the experimental respondents took an objectivist or subjectivist stance on issues of grading of offences and minimum requirements for offences. Experimentation is an unusual tactic in research concerning legal issues; other empirical techniques such as the examination of existing records or other archival procedures, or opinion surveys, are more common. Part of what we seek to demonstrate to criminal law theorists and code drafters is that this most rigorous form of scientific research, experimentation, can be brought to bear on their issues of debate. 
Subjects first read a paragraph of core information that gave the background to the various scenarios:

Please keep this general description of John in mind as you answer the following cases. Remember, you are always assigning a punishment to the character named John. In some of the scenarios other persons also deserve punishment, but we are not concerned with measuring that. We are only concerned with the punishment you would assign John.

Next they read a specific scenario and assign a liability to the perpetrator described in it. For instance, the murder scenario read as follows:

John is angry with prosecutor Paul for Paul's vigorous prosecution of John's father for income tax evasion. John feels the prosecution has ruined both his father's life and his own, and is intent on taking revenge. John buys an easily concealed gun, planning to confront and kill Paul in the parking lot of his office. As prosecutor Paul approaches his car in the parking lot of his office, John, standing several yards away, shoots and kills him. The sound of the gunfire draws security guards, who arrest John.

This is obviously a case of murder, and we use it to establish the sentence that the subject would give to murder committed in these particular circumstances. It is not likely to get different liability responses from objectivists and subjectivists. It provides a point of comparison for later cases-to see whether subjects thought the subsequent case deserved less liability and punishment than a straight murder case. No doubt some people will give higher punishment than others; for example, some may give the death penalty, while others, who are opposed to its use, will not. But using the experimental design we have chosen, whether the subject is a generally harsh or an easy sentencer, which is not the focus of our concerns, can be functionally excluded from our analysis. Our interest is in the difference in liability between specific scenarios, not the absolute amount of liability in any scenario.

As noted above, scenarios differ in ways designed to elicit one pattern of liability assignments if the subject takes an objectivist view, and another if the subject takes a subjectivist view. For instance, a second scenario read as follows:

John is angry with prosecutor Paul for Paul's vigorous prosecution of John's father for income tax evasion. John feels the prosecution has ruined both his father's life and his own, and is intent on taking revenge. John buys an easily concealed gun, planning to confront and kill Paul in the parking lot of his office. As prosecutor Paul approaches his car in the parking lot of his office, John, standing several yards away, shoots at him but misses. The sound of the gunfire draws security guards, who arrest John before he can get another shot at Paul.

The contrast between the two cases is clear: in both the intent is to murder, but in the second case the murder does not succeed, the harm has not occurred. Therefore the subjectivist should assign similar liability to both cases, while the objectivist would assign lower liability to the second case. 
Notice that we have attempted, and we hope succeeded, in making the two scenarios differ in only one way, the way that is relevant to the theoretical comparison in question. The subjects perceive the different scenarios as having the same overall characteristics, so that any differences in liabilities assigned can be attributed to the one characteristic that is varied between the contrasting scenarios.

The task of each subject, then, in response to each scenario was to assign a degree of liability and punishment to the protagonist in the scenario-in their view, to assign punishment to a wrong-doer. Subjects did this by marking their judgment on the scale shown below, a scale with which they quickly became familiar:

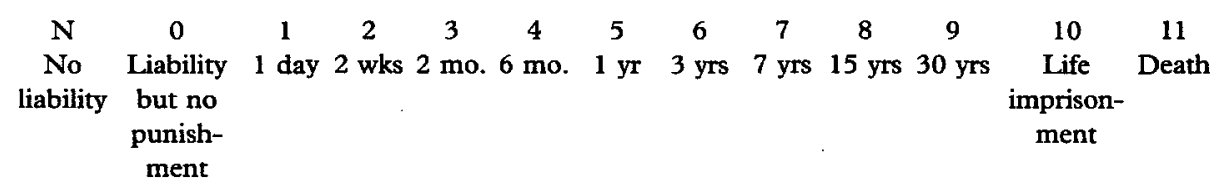

As can be seen, the scale gives subjects a choice of assigning no criminal liability to the protagonist, liability but no punishment, and 11 levels of punishment, prison sentences ranging from 1 day in jail to the death penalty. Notice that the length of the prison sentences increases differentially as the assigned punishments increase. For instance, an assignment of punishment level 2 is an assignment of 14 days in prison, an increase of only 13 days over punishment level 1 . An assignment of punishment level 9 is a 15 -year increase from the punishment represented by level 8 . We constructed the scale in this way for two reasons: First, and primarily, because the differences corresponded to the differences in grading categories used in typical American criminal codes. Second, because the differences corresponded, roughly at least, to what ordinary people perceive as equal differences between sentences. Thus these sorts of differences are the ones available to code drafters when they decide how to grade an offence, the ones juries and judges must deal with when sentencing a convicted offender, and perhaps the ones that come to the mind of citizens when they read and think about criminal sentences. ${ }^{20}$

In designing the scenarios, our task was to create as many as were needed to provide a reasonably complete test of the issues listed at the end of Section I. We found that 14 scenarios were needed. The full text of these scenarios are presented in the Appendix to this article. Some involve unconvictable perpetrator defences, an issue marked as an important test between the different theories of liability assignment, others involve variations in an actor's steps towards committing a crime, another area of difference. The exact differences at issue in contrasts between various scenarios we will describe in detail in Section III.

\footnotetext{
${ }^{20}$ The scale used here is the same as the one developed and first used in Paul H. Robinson and John M. Darley, Fustice, Liability, and Blame: Community Views and the Criminal Law (1995), in which we report the results of a number of studies that map the community's perceptions of the appropriate liabilities to assign in various criminal situations. For a more lengthy discussion of the scale and its properties, see ibid at 223-5.
} 
Pilot testing indicated that 14 cases could be read and evaluated by a subject in approximately half an hour. Further, the subjects were able to maintain concentration; their reports indicated that they found the task quite interesting, and were intrigued by thinking about what differences in cases 'made a difference' to them.

As this indicates, all of our subjects responded to all of the cases. In the experimental design literature, this is referred to as a 'within-subjects design'. This design focuses the subjects' attention on the differences between the scenarios. The danger is that they think that the existence of a difference implies an instruction from the researcher that the difference should 'make a difference'; that it should provoke different liability assignments from the subject. ${ }^{21}$ To counter this possibility, we told subjects that we did not expect that different scenarios necessarily should get different liability judgments, and that they were to give us their own judgments about what differences mattered. Looking over the individual response protocols, we noted that subjects did rate some cases alike as to the liabilities they generated.

As is usual in these designs, the order in which the cases were given to the subjects was randomized. To make the subjects' contrast task simpler for them, cases with one dimension of variation were grouped together. The order of cases within those groups was randomized, and the order in which the groups were presented was also randomized. Randomization prevents results from being dependent upon the order in which the scenarios were judged.

\section{B. The Sample of Subjects}

Any research study must select subjects from the population about which the research generalizations are intended to apply. Our concern is with the moral intuitions of the community of citizens governed by the laws in question. Since criminal laws are generally state laws, sometimes this consideration has guided us to select subjects from a particular state. Given that this research is about patterns of change in the rationale for criminal sentencing that exist at the national level, eventually one would want to construct a national sample of subjects. For this initial study of the issue, we were influenced by limitations imposed by practical considerations, and selected one set of our subjects from lists of jury-eligible citizens in a town in New Jersey. ${ }^{22}$ The second set consisted of college students. who are readily available for research. It is sometimes suggested that they are 'atypical', in that their responses would differ from 'ordinary people'. Since we had both students and 'ordinary people' in our research, we were able to test this contention.

We tested 27 students with an average age of 19.2 years and 21 jury-eligible community members with an average age of 50.8 years. Men and women were

\footnotetext{
${ }^{21}$ For a fuller discussion of the strengths and weaknesses of within-subjects designs in this sort of research, see ibid at 221-2.

22 Some $56 \%$ of those contacted to participate agreed to do so. This rather high rate of agreement was probably the result of the subjects' agreement with our explanation of the goals of the research.
} 
equally represented in both samples, as were the major religious denominations of Protestant, Catholic, and Jewish. ${ }^{23}$ Most in both samples identified themselves as politically moderate, with the students leaning a little more to the liberal side of the continuum. Students filled out the questionnaires in a room on campus; for the community members, questionnaires were mailed out to them, and occasionally after a telephone reminder, the questionnaires were mailed back to us. As expected, conservatives assigned slightly higher liabilities to the various scenarios we presented. Our jury-eligible community members also assigned slightly higher liabilities, over and above the fact that conservatives did so. What is important, for our purposes, is that the two groups of subjects did not show any significant difference in their pattern of relative liability assigned among the scenarios.

\section{Identifying Objectivist versus Subjectivist Views of Criminality}

Before performing the testing described in Part 2, we determined how an 'objectivist' and a 'subjectivist' would each respond to the test instrument. By comparing the actual responses to these benchmarks, we could determine whether a subject's response reflected an objectivist or subjectivist view of criminality, or something else.

Below we consider each scenario in turn. (Recall that the subjects did not receive the scenarios in this order; each received them in a different order.)

In scenario 1, the actor shoots and kills the victim, a simple completed conduct murder case. This case is meant to serve as a point of comparison to other cases below.

In scenario 2, the actor shoots to kill and misses, a completed conduct but failed attempt. The conduct and intention are the same as in scenario 1 . The only difference is that the death does not occur. The objectivist will impose liability reduced from that of the murder case because of the absence of the death. The subjectivist will not; the fortuitous failure to cause death does not make the actor less fit for liability in the subjectivist view. ${ }^{24}$

In scenario 3, the actor aims to shoot the victim but intervention by another person prevents the shooting. It is a case of an incomplete-conduct attempt, but one where the actor has come within a 'dangerous proximity' of the offence, as one of the common law tests of attempt would describe it. The objectivist would give a reduction in liability, perhaps more than the reduction given in scenario 2 for the completed conduct offence, because here the actor was further from

\footnotetext{
${ }^{23}$ Two of each sample were African-Americans, for a total of four in a panel of 48 .

${ }^{24}$ For attempted murder, the Model Penal Code makes an exception to its general rule that attempts are graded the same as the completed offence. See Model Penal Code s. 5.05(1) (second sentence). This is the most obvious exception that the Code makes in implementing its subjectivist view of criminality in the context of grading. For a discussion of why the drafters may have caved in on this particular application, see Paul $\mathrm{H}$. Robinson, 'The Role of Harm and Evil in Criminal Law: A Study in Legislative Deception?' 5 foumal of Contemporary Legal Issues 299-322 (1994) [hereinafter, Harm and Evil].
} 
completing the offence. The subjectivist will give no reduction in liability, as in the case of the completed conduct attempt in scenario 2 .

In scenario 4, the actor agrees with another that they will kill the victim, they go to look for a gun for that purpose. It is a case of a bilateral-agreement conspiracy, with no completed offence. The objectivist will be sceptical of this case; the conduct is even farther from the completed offence than in the 'dangerous proximity' attempt of scenario 3 . Perhaps it is too far to merit liability, but, on the other hand, the objectivist may see the group criminality here as a harm in itself. The actor has succeeded in forming at a criminal group. Thus, the objectivist may conclude that some liability is in order, albeit much reduced. The subjectivist will have no difficulty in finding adequate grounds for liability in this scenario. The actor has shown his illicit intention and his willingness to act upon it, thus no reduction in liability.

In scenario 5, the actor gives a gun to the person fighting with the victim hoping that the person will kill the victim, which he does. Current legal doctrine will consider this a case of complicity in murder. The objectivist is likely to reduce liability from that of scenario 1 because the actor's causal contribution is less than when he does the killing himself. The subjectivist will see the actor's intention to kill and his externalization of that intention and will impose full liability, the same as that in scenario 1 , just as current doctrine formally does.

In scenario 6, the actor gets a gun to help the person shoot to kill, but the person never receives the gun; he finds his own, then shoots and kills the victim. It is a case of attempted but failed complicity to a successful offence. The objectivist will give reduced liability for both of the reasons noted in scenarios 2,3 , and 5 . There is a death but the actor has no causal contribution to it, thus analogous to scenarios 2 and 3; also he is not himself the perpetrator but only an accomplice, as in scenario 5 . Thus, liability is likely to be even less than scenario 2 or 3 or 5 . The subjectivist will impose the same liability as in scenario 1; the actor intends to kill and has acted upon that intention.

In scenario 7, the actor shoots at a target, knowing there might be a person in the overshot zone, and kills a person. It is a case of reckless homicide, manslaughter. The objectivist will reduce liability from that in scenario 1 . Recall that the objectivist does not exclude the significance of an actor's culpability. Rather, the objectivist-subjectivist distinction is primarily driven by the subjectivist's rejection of the significance of objective factors-like resulting harm, or proximity to the completed offence. The subjectivist similarly will reduce liability because of reduced culpability, thus this case will be of no help in distinguishing the two views of criminality (but it will serve as a control case for scenario 8 , which will distinguish).

In scenario 8, the actor shoots at a target, knowing, as in scenario 7, that there might be a person in the overshot zone, but in this instance luckily no person is killed. It is a case of endangerment. The objectivist will give reduced liability from that in scenario 7 , where the death occurs. The subjectivist will not. The 
comparison is analogous to that between scenarios 1 and 2 , but at a lower culpability level. ${ }^{25}$

These eight scenarios present issues of grading; they test factors that might alter the grade of an actor's liability, but that are not likely to exculpate the actor from liability. In each instance, both objectivist and subjectivist are likely to agree that some liability is appropriate; the question is how much. In the next six cases there is some question whether or not liability should be imposed at all. They raise issues of the minimum requirements of liability.

In scenario 9, the actor gets a gun with the intention of going to find and kill the victim, but gets no further than this preliminary first step. It is what the Model Penal Code would call a case of 'substantial step' attempt. The objectivist would be troubled by the case; the actor's conduct is so far from the completed offence that it may not be sufficient for liability at all. Recall that the common law would give a defence in this case. The subjectivist would find adequate grounds for liability in the actor's intention to kill and his willingness to act upon that intention. The subjectivist who is a subjectivist in grading as well would give no defence. The subjectivist who is an objectivist in grading will want to give a discount, as was given in scenario 2 , but greater here because the conduct is further from the offence. Indeed, the liability reduction probably would be greater than that in scenario 3 because the substantial step attempt here is further from the offence than the dangerous proximity attempt there.

Scenario 9 introduces a point of complexity in the analysis. If we are correct in our prediction that the ordinary person is an objectivist on grading issues but a subjectivist on minimum requirements for liability, then for each of the scenarios testing minimum requirements issues, scenarios 9 to 14 , we would suggest two different reactions from subjectivists depending upon whether a person is a 'pure subjectivist,' a subjectivist in both minimum requirements and grading, and an 'objectivist-grading subjectivist', who shows the kind of discrimination that we predict, taking a subjectivist view in assessing the minimum requirements for liability but, once liability is to be imposed, reverts to an objectivist view in determining the amount of punishment.

In scenario 10 , the actor shoots the victim, as in scenario 1 , but the 'victim' turns out to be only a wax doll of the intended victim. It is a case of a completed conduct but factually impossible attempt. The objectivist will be troubled by this case. There was no real danger of commission. So a complete defence might be in order. On the other hand, this seems like more worrisome conduct. Unlike the legally impossible attempt to be discussed in scenario 13, it will be apparent to all observers here that the actor intended to kill the victim. The objectivist might reason that this kind of impossible attempt is itself a societal harm because it causes anxiety, invites retaliation by others, and generally destabilizes society.

\footnotetext{
${ }^{25}$ Despite its claim that the occurrence or absence of resulting harm ought not to influence the grade of the offence, as reflected in its grading of attempts the same as the substantive offence, the Model Penal Code does in fact grade endangerment dramatically less than reckless homicide (manslaughter). Compare Model Penal Code s. 210.3(1)(a) and (2) (manslaughter a second degree felony) to s. 211.2 (endangerment a misdemeanour). For a discussion and theory on why, see Robinson, Harm and Evil, above n. 24 at 312-22.
} 
Table I. Identifying objectivist and subjectivist responses

Scenario

1. Shoot to kill and kill-completed conduct murder-control

2. Shoot to kill and miss-completed conduct but failed attempt

3. Aiming gun but intervention before shoots-proximity but incomplete conduct

4. Agrees with another that they will kill the victim, they go to look for a

gun-bilateral conspiracy, no completed offence

5. Gives gun to person fighting with victim hoping will kill, perpetrator does then shoot and kill-complicity in murder 6. Gets gun to help person shoot to kill, but person never receives gun, perpetrator has to find his own gun, then shoots and kills-failed complicity, successful offence

7. Shoots at target, knowing there might be persons in the overshot zone, kills-manslaughter

8. Shoots at target, knowing there might be persons in the overshot zone, but luckily none-endangerment
Objectivist will say:

Subjectivist will say:

GRADING CASES

1. Murder control case

2. Reduced grade

3. Perhaps further reduction from no. 2 because further from completed offence

4. Probably less liability than no. 3 (and possibly even less than no. 9), because far from completed offence

5. Murder, but reduce liability to the extent that causal contribution is seen as less

6. Reduced grade, perhaps even more reduction than in no. 5 , because no causal contribution

7. Reduced grade from no. 1 (because of reduced culpability, $R$ rather than $P$ )

8. (Further) reduction from no. 7, analogous to that in no. 2
1. Murder control case

2. Same grade as completed offence in no. 1

3. No reduction, as in no. 2

4. No reduction, as in no. 2

5. Same grade as perpetrator in no. 1

6. Same grade as completed offence in no. 1

7. Same as objectivist: reduced grade from no. 1 (because of reduced culpability, $R$ rather than $P$ )

8. Same grade as no. 7 
9. Gets gun with intention to go to find the victim and kills-substantial step,

incomplete conduct

10. Shoots as in no. 1 but person turns out to be a life-like dummy of the

intended victim-completed conduct,

factually impossible attempt

11. Same as no. 4 but other is

undercover officer-unilateral conspiracy,

no completed offence

12. Smuggles cocaine - control case for

no. 13

13. Believes smuggling cocaine but only

talcum powder-completed conduct,

legally impossible attempt

14. Gives gun to person fighting with

victim who then kills, as in no. 5 , but

perpetrator turns out to be a person who

is acting and killing in self-

defence-assisting unconvictable

perpetrator
MINIMUM REQUIREMENTS CASES

9. Complete defence

10. Tempted to give complete defence, but perhaps some reduced liability because the appearance of an attempt can be a societal harm in itself

11. Complete defence

12. Smuggling control case

13. Complete defence

14. Complete defence
9. p-sbj-no reduction, as in no. 2 ; $\mathrm{o}-\mathrm{g}-\mathrm{sbj}$-reduction greater than in $\mathrm{ob} j$. no. 2 or 3

10. p-sbj-no reduction, as in no. 2 ; $\mathrm{o}-\mathrm{g}$-sbj-reduction, as in obj. no. 2

11. p-sbj-no reduction, as in no. 4 (same grade as no. 2); o-g-sbj-same reduction as in obj. no. 4

12. Control

13. p-sbj-no reduction from no. 12 ; $\mathrm{o}-\mathrm{g}$-sbj-reduction, proportionate to that in obj. no. 10

14. $\mathrm{p}$-sbj-no reduction, as in no. 5; o-g-sbj-reduction in obj. no. 2 plus reduction in obj. no. 5

o-g-sbj = objectivist-grading subjectivist

$\mathrm{p}$-sbj $=$ pure subjectivist. 
In fact, the common law history reflects uncertainty on these kinds of cases, initially providing a complete defence but subsequently allowing liability but at a reduced level..$^{26}$ The subjectivist, as in the other attempt cases will easily find the manifested intention and the willingness to act upon it as adequate grounds for liability. The 'pure subjectivist', who is a subjectivist in grading as well, will provide no reduction, as with all inchoate conduct. The 'objectivist-grading subjectivist', who is an objectivist on grading issues, will give a reduction in liability because of the absence of the offence harm, as in scenario 2, which is also a completed conduct attempt.

In scenario 11, the actor conspires with another to kill the victim, as in scenario 4 , but the other conspirator in this instance is an undercover police officer, so there was never any real danger of the offence being committed. The case is one of unilateral conspiracy with no completed offence. The absence of any danger of commission makes the offence analogous to that of an impossible attempt. This will trouble the objectivist, as it did the common law, which gave it a complete defence. The subjectivist will be comfortable imposing liability here, as in scenario 4 . The pure subjectivist will again give full liability; the objectivistgrading subjectivist will give the same reduction in liability given in scenario 4, because of the absence of the intended death.

In scenario 12 , the actor smuggles cocaine. It is a control case, like scenario 1 , in this instance providing a point of comparison for scenario 13. (The issue being tested here-legally impossible attempt - does not arise in result element offences, such as homicide, hence the need to switch to a different base offence.)

In scenario 13, the actor believes he is smuggling cocaine but in fact is only carrying talcum powder. This is a case of a completed conduct legally impossible attempt. The objectivist will give a complete defence because the danger of commission of an offence existed only in the actor's mind (and here, unlike the case of factually impossible attempt, there is not the same potential for triggering public anxiety or private retaliation). The subjectivist will not provide a defence. The pure subjectivist will give the same liability as given in scenario 12. The objectivist-grading subjectivist will reduce liability out of recognition of the absence of the offence harm. It will be a reduction proportionate to that given in scenario $10,{ }^{27}$ because the difference between a factually and a legally impossible attempt will be of little significance to the subjectivist (as it is irrelevant in modern codes).

In scenario 14 , the actor hopes to have the victim killed by giving a gun to a person fighting with victim; the person does use it to kill the victim, as occurred in scenario 5 , but in this instance the killer turns out to be acting in lawful selfdefence. Thus, it is a case of assisting an unconvictable perpetrator. The objectivist will give a complete defence. The killing is analogous to an impossible attempt,

\footnotetext{
${ }^{26}$ For a statement of the old rule, see Regina v Collins 9 Cox CC 497 at 499 (1864). English law now rejects all forms of impossibility as a defence. See Andrew Ashworth, Principles of Criminal Law (1991) at 405-6.

${ }^{27}$ We say 'proportionate' because we would expect that the murder will have a higher liability than the smuggling, thus we would expect that the actual amount of the discount in the smuggling case would be proportionately less.
} 
where the actor wants to commit an offence but, because of circumstances unknown to him, is legally unable to do $\mathrm{so}^{28} \mathrm{He}$ in fact helped a person do the right thing. ${ }^{29}$ As in scenario 13 , the objectivist gives a complete defence to a legally impossible attempt. The actor may have had the culpability required for the offence, but there was no real danger of the offence being committed. The danger only existed in the actor's mind. The subjectivist will impose liability: the pure subjectivist giving full liability, as in all inchoate offences; the objectivistgrading subjectivist will give a discount analogous to that of the completed conduct attempt in scenario 2, plus a discount similar to that in scenario 5 because the actor is only an accomplice, not the perpetrator.

Table I summarizes these analyses.

\section{The Results and Their Implications for the Questions Presented}

\section{A. The Results}

The liability results of the study are reported in Table II. The second column reports for each scenario the mean of subjects' responses assigned to that scenario on the liability scale described in Part 2 . Recall that each point on the scale corresponds to about one grade in the average American criminal code grading scheme. For scenario 1, the straight murder case, liability is predictably high, 10.10. Using this as a reference, we can see whether subjects impose less liability in other cases and, if so, how much less. ${ }^{30}$

\section{(i) Issues of offence grading}

Consider the first eight scenarios, in which everyone would agree that some liability is appropriate; the only issue is what degree of liability should be imposed. Those who take a subjectivist view of grading offences will regard scenarios 2 to 6 as equivalent to murder. In all of them, an intent was formed and displayed, and the intent was to commit murder. Those taking an objectivist view, in which the occurrence of harm and other considerations are taken into account for the reasons discussed in Part 3 (see Table I), will see these offences as calling for less liability than the prototypical murder case.

\footnotetext{
${ }^{28}$ For a discussion of this analogy, see Paul $\mathbf{H}$. Robinson, 'Competing Theories of Justification: Competing Theories of Justification: Deeds vs Reasons' in A.T.H. Smith and A. Simester (eds) Current Problems of Criminal Theory (Oxford, 1996) at 45-70.

${ }^{29}$ The reader will later hear that the subjects may have perceived this scenario in a way different from that which we intended; our intended meaning is described in the text here. See the later discussion at text before $n$. 32 .

${ }^{30}$ Our task is to examine for differences between the average assignments of liability to two or more cases. The question immediately arises concerning which differences are real, and which might have been produced by some random process such as a succession of coin flips. The custom in social science research is to treat differences that could have occurred only five times out of 100 by chance as not produced by chance, and as 'real' and therefore interpretable differences. All of the differences that we discuss and interpret could occur only one time out of 100 , unless we note otherwise.
} 
Table II. Liability results and their objectivist-subjectivist implications

\begin{tabular}{|c|c|c|c|c|}
\hline Scenario & Mean & $\begin{array}{l}\text { Grading }(G) \\
\text { or minimum } \\
\text { requirements } \\
\text { (MR) case? }\end{array}$ & $\begin{array}{l}\text { Consistent } \\
\text { with } \\
\text { objectivist } \\
\text { view? }\end{array}$ & $\begin{array}{l}\text { Consistent } \\
\text { with } \\
\text { subjectivist } \\
\text { view? }\end{array}$ \\
\hline (1) Murder & 10.10 & - & - & - \\
\hline $\begin{array}{l}\text { (2) Completed conduct } \\
\text { attempted murder }\end{array}$ & 8.38 & G & Yes & No \\
\hline $\begin{array}{l}\text { (3) Incomplete conduct } \\
\text { (proximity) attempt in murder }\end{array}$ & 7.33 & G & Yes & No \\
\hline $\begin{array}{l}\text { (4) Bilateral inchoate } \\
\text { conspiracy }\end{array}$ & 6.06 & $G$ & Yes & No \\
\hline (5) Complicity in murder & 8.60 & G & Yes & No \\
\hline $\begin{array}{l}\text { (6) Failed complicity in } \\
\text { murder }\end{array}$ & 6.35 & G & Yes & No \\
\hline $\begin{array}{l}\text { (7) Manslaughter (reckless } \\
\text { homicide) }\end{array}$ & 7.15 & G & Yes & Yes \\
\hline (8) Endangerment & 5.28 & $\mathbf{G}$ & Yes & No \\
\hline $\begin{array}{l}\text { (9) Incomplete conduct } \\
\text { (substantial step) attempt to } \\
\text { murder }\end{array}$ & 5.73 & MR & No & Yes (obj-grd) \\
\hline $\begin{array}{l}\text { (10) Completed conduct } \\
\text { factually impossible attempted } \\
\text { murder }\end{array}$ & 7.94 & MR & Yes & Yes (obj-grd) \\
\hline $\begin{array}{l}\text { (11) Unilateral inchoate } \\
\text { conspiracy }\end{array}$ & 6.29 & MR & No & Yes (obj-grd) \\
\hline (12) Smuggling cocaine & 7.40 & - & - & - \\
\hline $\begin{array}{l}\text { (13) Legally impossible attempt } \\
\text { to smuggle cocaine }\end{array}$ & 5.06 & MR & No & Yes \\
\hline $\begin{array}{l}\text { (14) Mistaken belief of } \\
\text { complicity in murder }\end{array}$ & 9.0 & MR & No & $\begin{array}{l}\text { Yes (obj- } \\
\text { grd)* }\end{array}$ \\
\hline
\end{tabular}

obj-grd = subjectivist of the objectivist-grading type.

* But see text discussion concerning scenario 14 .

The results of the study tell a simple story: the objectivist view of grading is the one adopted by our subjects. In all of the comparison cases, the liability assignments are lower than that assigned to the murder scenario. In scenario 2, the completed conduct attempted murder case, subjects impose liability of 8.38. The absence of intended harm, which is the only difference between scenario 1 and scenario 2, generates a reduction in liability of about 1.7 grades (a 'no-harm discount' as it might be called.)

Scenario 3 is an attempt case, like scenario 2 , but one in which the conduct is not complete; the actor is stopped before he can shoot, what the common law 
called a 'dangerous proximity' attempt. The subjects give a liability of 7.33 , a further discount from the failed attempt in scenario 2, where the actor shoots and misses. It appears that the subjects are giving an additional discount because the actor is further from commission of the offence; this might be called a 'incomplete-conduct discount'. Tentatively, we might think of this discount as being added to the no-harm discount

Scenario 4 is the bilateral inchoate conspiracy. The subjects give a reduction in liability, to 6.06 , well below the murder scenario of 10.10. The liability assigned scenario 4 is also below the liability assigned to scenario 3 . This latter difference may represent an additional incomplete-conduct discount thought appropriate because the conduct is even further from the completed offence than in the dangerous proximity attempt in scenario 3.

In scenario 5 the actor is only complicit in murder; the murder occurs but he is an accomplice rather than the perpetrator of the murder, and is assigned a liability of 8.60 , considerably lower than the liability assigned the murderer in scenario 1. Such a 'complicity discount' is consistent with an objectivist view of criminality; the actor appears to have less of a causal responsibility for the death.

Scenario 6 presents the case of failed complicity in murder, assigned a liability of 6.35. The subjects give a substantial reduction, not only reduced from the liability of scenario 1 but also from the liability imposed in scenario 2, completed conduct attempt, and that imposed in scenario 5, complicity. But such greater reduction is entirely consistent with an objectivist view of criminality. The actor is not only in the role of accomplice rather than perpetrator, as in scenario 5, but he also has no actual causal connection with the death; his conduct only constitutes an attempt, as in scenario 2. Interestingly, it appears that the no-harm discount and the complicity discount work additively, to provide a cumulative reduction in punishment.

In scenarios 7 and 8 , the intent to kill present in other scenarios is absent; instead the actor is only reckless as to causing the death. In scenario 7 , the reckless homicide case, the subjects impose liability of 7.15, a reduction from the straight murder case in scenario 1. As noted in the analysis in Part 3, we did not expect the contrast between this scenario and the murder scenario to distinguish between an objectivist and a subjectivist view of criminality by the subjects; both views would give reduced liability because of the actor's reduced level of culpability. These results confirm our prediction of an 'unintended result discount.'

The comparison of most interest for scenario 7 is with scenario 8 . Scenario 8 is the same as scenario 7 except that the harm risked luckily does not come about. The subjects reduce liability from the 7.15 of scenario 7 , to 5.28 . This seems to provide not only an unintended result discount but also the no-harm discount that we saw in scenario 2. Again, we see that the two discounts appear to be additive.

To sum up what we found for the grading issues, the patterning of the subjects' responses to these scenarios is quite consistent and strongly suggests that they 
take an objectivist view of criminality on issues of grading; resulting harm and the extent of causal contribution to a harm are highly relevant to their assignment of liability.

\section{(ii) Issues of offence minimum requirements}

We turn next to an examination of the remaining scenarios, in which the issue is the minimum requirements of criminal liability. Recall that in these cases, there is argument by some that no liability should be imposed. The objectivist holds that if there was no actual danger of harm occurring, then no liability ought to generated, even though the actor intended harm. The subjectivist holds that when a settled intent to do harm is formed, liability ought to be generated. The pure subjectivist would have the same degree of liability imposed no matter whether the harm actually occurs and no matter the actor's causal contribution to it, if any. As noted above, however, the objectivist-grading subjectivist concedes that the liability generated ought to depend upon whether the harm actually occurs and the extent of the actor's causal connection to the harm.

In these minimum requirements comparisons, the subjects show themselves to be subjectivists, rather than the objectivists that we saw when considering the grading scenarios. More precisely, they show themselves to be, as a group, objectivist-grading subjectivist. That is, they take a subjectivist view of minimum requirements but, in imposing that liability, they reveal their objectivist approach to grading.

Scenario 9 is the substantial step attempt case. The subjects' assigned liability averaging 5.73 sharply reduced from the relevant contrast case of murder. The fact that any liability is assigned is inconsistent with the objectivist view, which would have given a complete defence and therefore assign no liability because there had not yet been any real danger of the offence being committed. We note that no liability would have been the actual result of application of the common law test in such a substantial step case.

The reduced liability assigned by the subjects is consistent with the objectivistgrading subjectivist's view. It seems to reflect a no-harm discount and, because the offence is so far from completion, a double incomplete-conduct discount. This case is even more distant from a completed offence than the proximity attempt in scenario 3, hence liability is even lower that the 7.33 in that scenario. This supports the theory that the subjects as a group are objectivist as to grading, but subjectivist as to minimum requirements. If their subjectivist minimum requirements are met, they shift to their objectivist view to determine how much liability to impose.

Scenario 10 is the completed conduct, factually impossible attempt scenario; the actor shot a wax dummy in the head, mistaking the dummy for his enemy. Recall that this is a case that objectivists will be torn over, just as early common law gave a complete defence but later permitted reduced liability. It probably will not surprise the reader to learn that the subjects 
assigned an average liability of 7.94, which is certainly generally inconsistent with the early common law position of giving a defence, although one subject gave liability but no punishment. The rather high average liability assigned in this condition is perhaps something more than one might expect from an objectivist. ${ }^{31}$ It is, however, entirely consistent with the objectivist-grading subjectivist who, after determining that liability is appropriate because of the actor's externalized intent, reverts to an objectivist view in determining the amount of liability. In comparison to the completed conduct (possible) attempt of scenario 2 , which received a liability of 8.38 , the results here hint at the subjects providing an additional discount, beyond that for no harm; they seem to be giving a discount that takes account of the factual impossibility of actually causing the intended harm. However, the reliability of the difference between these two cases is marginal $(P=0.07)$.

Scenario 11 is a unilateral inchoate conspiracy case; the co-conspirator is an undercover police officer. The subjects give liability of 6.29. This is inconsistent with the objectivist view, which would give a complete defence. The imposition of liability by the subjects is consistent with the objectivistgrading subjectivist's view. Again it does not follow the pure subjectivist pattern of having no reduction in liability from the prototypic murder case. Instead, it reflects the view of a subjectivist who, after determining that the minimum requirements of liability are satisfied, shifts to an objectivist view in judging the amount of liability to impose. The extent of liability is slightly below that imposed in scenario $9(P=0.03)$; both deserve a no-harm discount as well as a double incomplete-conduct discount. Conspiracy to murder is not murder.

An interesting comparison for the unilateral conspiracy case is scenario 4, an analogous conspiracy case, but one in which the co-conspirator is real, not a police officer. The status of the co-conspirator is irrelevant to the subjectivist, because it is outside the knowledge of the actor. Our subjects assigned nearly equivalent liability to the two cases (actually slightly but not reliably higher for the unilateral conspirator) which is what one would expect from a subjectivist view.

Scenarios 12 and 13 involve a drug smuggling offence rather than murder, and thus are not to be compared to any of the other scenarios. In scenario 12, the offender smuggles cocaine and receives a liability of 7.40. In scenario 13, which is identical but for the fact that, unknown to the actor, the powder he

\footnotetext{
31 The concerns that the objectivist is struggling to express, and the reasons for her discomfort, are revealed in Norman Finkel, Stephan Maloney, Monique Vailbuena, and Jennifer Groscup, 'Lay Perspectives on Legal Conundrums: Impossible and Mistaken Act Cases' 19 Law and Human Behavior 593-608 (1995). Using a scenario methodology and varying the impossible act cases, they demonstrate that, if the perpetrator completes an act that any reasonable person would agree was going to bring about the death of the victim, judgments of 'guilty' are made even if that act did not in fact bring about death. (They did not have their subjects assign degrees of liability, so we cannot tell if some of those judgments of 'guilty' would have led to reduced punishments.) However, when the act the perpetrator completed was not one that a reasonable person would think would be effective in bringing about death, then judgments of 'guilty' were infrequent. The scenario that most clearly makes this point is one in which the perpetrator attempted to bring about death by sticking pins into a wax effigy of the intended victim.
} 
smuggles is not illegal drugs but talcum powder, liability drops to 5.06 . The fact that substantial liability is imposed by the subjects is inconsistent with an objectivist view, which would give a complete defence. The subjects' response is consistent with an objectivist-grading subjectivist's view. The reduction we see here is similar to the no-harm plus impossibility reduction that we first saw in scenario 10, a bit more than two grades. Again, the pure subjectivist would give no reduction.

Scenario 14 is the case that seemed to try our subjects' analytic thinking (or possibly their patience) most. Recall that the case involves a belief by the actor that he is being an accomplice to murder, when it turns out that he is actually giving a gun to a person who uses it to kill another in self defence. The subjects assign a liability of 9.0 . This is inconsistent with the objectivist view, which would give a complete defence because the case is analogous to that of a legally impossible attempt in the sense that the actor mistakenly believes that the circumstances are such that he is committing an offence when in fact he is mistaken about the circumstances. From the objectivist perspective, his conduct is entirely lawful; it is only from his mistaken view of the circumstances that his conduct would be seen as an offence.

But neither does the case seem to be graded according to the objectivistgrading subjectivist's view, which we have seen reflected in all of the previous zases. Under that view, the actor probably would have been entitled to both a somplicity discount and a no-harm discount, in other words, liability in the range of 7 rather than the 9.0 that the subjects in fact assign. That is, subjects are treating the death as an actual harm for which the actor deserves punishment, ather than a justified harm that was entirely lawful.

How did our subjects think about this case? We were sufficiently interested $\mathrm{n}$ determining this that we asked 10 new subjects to react to this case along with scenario 5 , the case of complicity to murder; recall that in both cases he actor gives the perpetrator a gun, intending to assist the perpetrator in nurdering the other. In both cases the other is killed; in one it turns out to se in self-defence, in the other murder. But, and obviously, the two cases ure identical from the perspective of the actor on whom we focus. Subjects nade their liability assignments, and we interviewed them about how they aw the two cases. Subjects had trouble with this comparison, because they vere torn between the two conflicting considerations, considerations that they ecognized and articulated. Because they were compelled by the fact that the ıct was an identical one from the perspective of the actor, two of the ten ubjects gave the two cases identical and high liabilities. The other eight ubjects recognized this, but also recognized that the resultant killing was elf-defence in one case, and reduced the liability they assigned (usually a ine grade reduction, occasionally a little more) without being able to articulate reason for this other than they thought the actor should 'get a little eduction' from the prototypic case. The force of the subjectivist perspective s revealed here, but the typical result makes the case inconsistent with the 
pure subjectivist view, which would be to give no discount. Instead, our subjects reverted to the objectivist view in grading. ${ }^{32}$

To review these minimal requirement contrasts, the subjects as a group take the objectivist-grading subjectivist view, using subjectivist criteria to determine whether liability should be imposed but reducing that liability as a grading objectivist would, giving discounts for no harm, complicity, impossibility, incomplete conduct, and unintended consequences.

\section{(iii) An analysis of response patterns of individual subjects}

The previous section has examined the responses of the subjects as a group and that examination has painted a relatively clear picture of our subjects as objectively grading subjectivists. But we worried that treating the subjects as a group might hide important differences among the subjects as individuals. We wondered, for example, whether the group means might be the result of a majority of objectivegrading subjectivists outvoting a minority of pure subjectivists, or pure objectivists. Or, perhaps, the objective-grading subjectivists were not really the bulk of the group; perhaps the means simply reflected shifting majorities among polar opposites of pure subjectivists and pure objectivists. In fact, our examination of the subjects' responses as individuals did reveal a picture that is slightly different in important ways.

Most of the grading scenarios still suggested a strong objectivist view. The vast majority of the subjects gave reduced liability (compared to the control case of scenario 1) in scenarios $2,3,4,6$, and $7: 90 \%, 98 \%, 98 \%, 96 \%$, and $98 \%$ of the subjects, respectively. Of course, this means that up to $10 \%$ of the subjects gave no reduction, the subjectivist view.

The subjectivist view, while still a minority view, seemed to be stronger in two scenarios in particular. In scenario 5 , complicity in murder, only $65 \%$ of the subjects gave reduced liability; thus $35 \%$ thought the complicity ought to be equivalent in liability to murder. Also interesting is scenario 8 , in which $58 \%$ of the subjects gave reduced liability, but $42 \%$ did not. That $42 \%$ of the subjects did not reduce liability is a bit of a surprise. No jurisdiction grades endangerment, simple risk-creation, the same as manslaughter, recklessly causing a death. We did not predict either of these results. It would be interesting to learn more in future research about that substantial minority of the subjects who disagreed with the majority view and who believed that complicity and lack of a harm from risk-taking ought not to reduce liability.

The minimum requirements scenarios also offered some surprises when the individual subject responses were examined. A majority of subjects performed in a way consistent with the picture offered by the means analysis above. That is, a majority of subjects showed a subjectivist view in imposing liability but

\footnotetext{
32 It is not entirely clear to us why the original subjects of the larger study did not see the need for reduction that our later subjects saw. Perhaps we asked too much of them in making the complex calculation, and in expecting their response to match all other scenarios as they would have wanted. When faced with the simple comparison of just two scenarios, in the second testing, their task was easier and their decision clearer.
} 
switched to an objectivist view in grading. However, a few pure objectivists did exist. In each of the minimum requirements scenarios, a few subjects assigned either a rating of 'no liability', or 'liability but no prison sentence'.

In scenario 9 , the substantial step murder attempt, four persons, or $8 \%$ of the sample, showed an objectivist assignment of no liability; three others generated the complex judgment that the attempter was liable, but should be assigned no punishment. ${ }^{33}$ In scenario 11 , the unilateral inchoate conspiracy, three subjects assigned no liability and two more assigned liability but no punishment, a total of $10 \%$ of the subjects. Perhaps most interesting, in scenario 13, the legally impossible attempt to smuggle cocaine (that was actually talcum powder), a majority imposed a substantial punishment, but $23 \%$ (11 people) gave the objectivist response: six no liability and five no punishment. In its weakest showing, the objectivist-grading subjectivist view was held by only $77 \%$ of the sample.

One more aspect of the data warrants examination. Do our individual subjects show a consistent view in their responses? That is, if an individual gives, for instance, an objectivist response.$^{34}$ to one scenario, is he or she also likely to give an objectivist response to other scenarios? The answer is 'yes'; the data indicate moderate consistency among subjects. As mentioned before, seven subjects gave the pure objectivist response to the minimum requirements scenario 9. All of the subjects who gave a pure objectivist response to scenarios 10 and 11 were drawn from that group of seven. Five out of that seven also gave the pure objectivist response to scenario 13. Clearly, a small subset of our sample tended towards objectivist responses on minimum requirements scenarios. These might be called 'pure objectivists' because, like the majority, they also gave objective responses in the grading scenarios.

Did we find any 'pure subjectivists', persons who gave not only the usual subjectivist responses to minimum requirements cases but also to grading cases? Yes. One consistent subjectivist and other occasional subjectivists. That is, one subject assigned liabilities identical to the liability he gave to the murder case to scenarios $2,3,4,9,10$, and 11 ! As far as this subject was concerned, shooting to kill and missing, or aiming the gun and being stopped by a security guard, or shooting a wax doll mistaken for the target ought to generate the same liability as killing, as should conspiring to kill the other, whether unilateral or bilateral, and as should buying a gun for the purpose of killing the other. Four other subjects joined this one, thus $10 \%$ of the sample, in assigning similar liabilities to the murder scenario and the shooting to kill but missing scenario (scenarios 1 and 2). Four different subjects joined the first one, again, $10 \%$ of the sample, in assigning an identical liability to murder and shooting a wax figure mistaken for the target (scenarios 1 and 10 ).

\footnotetext{
${ }^{33}$ For a discussion of the interesting implications of a subject's use of the 'liability but no punishment' verdict, iee Robinson and Darley, above n. 20 at 210-12.

${ }^{34}$ For the purposes of this discussion, we define an objectivist response as one that assigned either the 'no iability' or the 'liability but no punishment' verdict.
} 
To summarize, while the vast majority took an objectivist view of grading, a small minority took a subjectivist view in some cases (only one subject was consistently a grading subjectivist). Two of the grading scenarios (complicity and endangerment) revealed a more substantial minority of grading subjectivists. While the vast majority of subjects took a subjectivist view of minimum requirements (with objectivist grading again, of course), a small minority of pure objectivists seemed to exist.

\section{B. Implications of the Results for the Questions Presented}

Recall the questions presented at the conclusion of Part 1:

(1) Do people take an objectivist view, as the common law did, on both grading and minimum requirements issues, or do they prefer a subjectivist view, as modern criminal codes seem to? That is, are people of today Fletcher's 'traditionalists' or, as Fletcher would seem to predict by his labeling, 'modernists'?

(2) Are people consistent in the view they take? That is, do they stick to an objectivist view, or a subjectivist view, in a variety of situations? Or do they switch back and forth in a way that suggests that they cannot properly be characterized as taking either view?

(3) If people are not consistently 'traditionalists' or 'modernists', as Fletcher predicts, is there nonetheless a discernible pattern in their use of an objectivist or a subjectivist view? Do people take a subjectivist view in judging the minimum requirements for liability and an objectivist view in grading, as we hypothesize? Or does the pattern follow a different principle? Or, is there no underlying pattern to peoples' liability preferences, as some writers would seem to expect?

The reader now knows from our description of results that most lay persons today are neither 'modernists' or 'traditionalists', as Fletcher seems to assume, and certainly they are not 'modernists', as that label predicts. There does appear to be a consistent pattern in the typical subject's views: a subjectivist view in judging the minimum requirements of liability, but a shift to an objectivist view in assessing the proper grade of an offence. This was the pattern we hypothesized.

When it comes to setting the minimal requirements for conduct to count as a crime, the vast majority of subjects take a subjectivist view: a person who intends to commit a crime, and carries out conduct towards the direction of committing that crime, is assigned criminal liability, even when the crime and the harm does not ensue and even when it would have been impossible to ensue.

In determining how much liability to impose upon the offender, however, the subjects were acutely sensitive to such considerations as whether the harm actually occurred, whether the actions intended to bring about that harm were complete or incomplete, and the strength of the actor's causal connection with the harm, including whether the actor was the perpetrator or only an accomplice. They certainly did not agree with the core proposition of the subjectivist view on grading, that forming an intent to commit harm is always morally equivalent to causing that harm, and should generate equivalent liability. 


\section{Modeling the Liability Assignments: the Discounting Dynamic}

To give a better sense of the patterning of our subjects' judgments, we sketch a set of liability assignment rules that are consistent with our findings and that produce liability assignments similar to those given by the subjects. (As the empirically trained reader will recognize, it is always the case that a number of conceptual models can be generated that could fit the existing data patterns.) In the model we propose, the liability assignment process would begin with the concept of the prototypical crime, in this case of murder, and the appropriate sentence for that crime. The differing sentences for prototypes of differing crimes is not something we have investigated in detail in the present research, but the idea is generally accepted. Some offences are more 'serious' than others and deserve higher sentences. Murder deserves a greater punishment than theft, or as in our study, murder deserves and gets a higher punishment than cocaine smuggling. ${ }^{35}$

Various classes of deviations from the prototype would cause a reduction in sentence. In this study, which considers cases that lie on the borderlines between some of the most complex issues in criminal law theory, we found that five kinds of discounts were sufficient to represent all of the deviations from prototype: a no-harm discount, an incomplete-conduct discount, a complicity discount, an unintended result discount, and an impossibility discount. Table III shows how these five discounts, combined in different ways, can account for the variations in means seen in the subjects' liability responses.

The apparent additive nature of the various discounts is an interesting implication of this study's results, and future research might test it further. Are such 'discounts' additive in other situations? Is the proportion of discount similar in different situations, or is it entirely situationally dependent? Although this study was not designed for the purpose, we might thought it interesting to try to examine these questions with our current data.

By comparing cases which differed only on one of the kinds of discounts, we can examine the magnitude of the discount that the subjects judged appropriate. Column 3 of Table III lists some of the comparisons possible. For some of the discounts, we were able to derive more than one estimate of the discount from the data. For instance, the non-occurrence of the harm, what Table III refers to as the 'no-harm discount', can be estimated by contrasts between scenarios 1 and 2 , but also by scenarios 5 and 6 , and scenarios 7 and 8 . If we had multiple estimates of a discount, we averaged them. These average discount estimates are shown in Table IV, column 5.

As can be seen when multiple estimates are possible, the different estimates of the discounts vary considerably. This, then, suggests our first conclusion: something about the specific circumstances in which the discount is instantiated seems to make a difference in the degree of sentence reduction from the prototype

\footnotetext{
${ }^{35}$ For a discussion of the seriousness of the offence as a determinant of liability, see Robinson and Darley, above n. 20 at $158-9,224-5$.
} 
Table III. A discounting model of grading

\begin{tabular}{|c|c|c|}
\hline Scenario & Mean & Implication of comparisons \\
\hline (1) Murder & 10.10 & [control case] \\
\hline $\begin{array}{l}\text { (2) Completed conduct attempted } \\
\text { murder }\end{array}$ & 8.38 & vs (1): no-harm discount \\
\hline $\begin{array}{l}\text { (3) Incomplete conduct } \\
\text { (proximity) attempt in murder }\end{array}$ & 7.33 & $\begin{array}{l}\text { vs }(1) \text { : no harm }+ \text { incomplete- } \\
\text { conduct discount } \\
\text { vs }(2) \text { incomplete-conduct } \\
\text { discount }\end{array}$ \\
\hline (4) Bilateral inchoate conspiracy & 6.06 & $\begin{array}{l}\text { vs }(1) \text { : no-harm }+ \text { double } \\
\text { incomplete-conduct discount } \\
\text { vs }(3) \text { : additional incomplete- } \\
\text { conduct discount }\end{array}$ \\
\hline (5) Complicity in murder & 8.60 & vs (1): complicity discount \\
\hline (6) Failed complicity in murder & 6.35 & $\begin{array}{l}\text { vs (1): no-harm + complicity } \\
\text { discount } \\
\text { vs (5): no-harm discount (no } \\
\text { causal connection with harm) }\end{array}$ \\
\hline $\begin{array}{l}\text { (7) Manslaughter (reckless } \\
\text { homicide) }\end{array}$ & 7.15 & vs (1): unintended result discount \\
\hline (8) Endangerment & 5.28 & $\begin{array}{l}\text { vs (1): unintended result }+ \text { no } \\
\text { harm discount } \\
\text { vs ( } 7) \text { no harm discount }\end{array}$ \\
\hline $\begin{array}{l}\text { (9) Incomplete conduct } \\
\text { (substantial step) attempt to } \\
\text { murder }\end{array}$ & 5.73 & $\begin{array}{l}\text { vs (1): no-harm + double } \\
\text { incomplete-conduct discount } \\
\text { vs (2): double incomplete-conduct } \\
\text { discount } \\
\text { vs (3): incomplete-conduct } \\
\text { discount }\end{array}$ \\
\hline $\begin{array}{l}\text { (10) Completed conduct factually } \\
\text { impossible attempted murder }\end{array}$ & 7.94 & $\begin{array}{l}\text { vs }(1) \text { : no-harm + impossibility } \\
\text { discount } \\
\text { vs (2): impossibility discount }\end{array}$ \\
\hline (11) Unilateral inchoate conspiracy & 6.29 & $\begin{array}{l}\text { vs (1): no-harm + double } \\
\text { incomplete-conduct discount } \\
\text { vs }(4) \text { : analogous discounts } \\
\text { [control casel }\end{array}$ \\
\hline $\begin{array}{l}\text { (12) Smuggling cocaine } \\
\text { (13) Legally impossible attempt to } \\
\text { smuggle cocaine }\end{array}$ & $\begin{array}{l}7.40 \\
5.06\end{array}$ & $\begin{array}{l}\text { [control case] } \\
\text { vs (12): no-harm + impossibility } \\
\text { discount }\end{array}$ \\
\hline $\begin{array}{l}\text { (14) Mistaken belief of complicity } \\
\text { in murder }\end{array}$ & 9.0 & $\begin{array}{l}\text { vs }(5) \text { similar means, suggesting } \\
\text { that only complicity discount given } \\
\text { (no no-harm discount given)* }\end{array}$ \\
\hline
\end{tabular}

* But see text discussion concerning scenario 14 . 
Table IV. Estimate of discount size

\begin{tabular}{lllll}
\hline Discount & Estimate 1 & Estimate 2 & Estimate 3 & Average \\
\hline No-harm & $1.72(1 \vee 2)$ & $0.25(5 \vee 6)^{*}$ & $1.87(7 \vee 8)$ & 1.28 \\
Complicity & $1.50(1 \mathrm{v} 5)$ & & & 1.50 \\
Unintended result & $2.95(1 \mathrm{v})$ & & & 2.95 \\
Impossibility & $2.34(12 \mathrm{v} 13)$ & $0.44(2 \mathrm{v} \mathrm{10)}$ & & 1.39 \\
Incomplete conduct & $1.05(2 \mathrm{v} 3)$ & $1.27(3 \mathrm{v} 4)$ & $1.6(3 \vee 9)$ & 1.31 \\
\hline
\end{tabular}

* This is a scenario where the harm does occur but the actor has no causal connection to it. Perhaps this difference is important to the subjects.

NB: The parentheticals indicate the two scenarios whose liability results are compared in order to generate the value of the discount.

that the subjects assigned; the amount of a discount given seems to be to some extent situationally dependent. What variations in circumstance 'make a difference' to our subjects is a question for further research; the study we report here, it will be recalled, was not designed to quantify discounts.

Another conclusion suggested by Table IV is that four of the five discounts each seem to be of approximately the same amount, something more than one but less than two. Remember that each point on the liability scale represented approximately one offence grade in a typical American criminal code, and that the difference between points was different; the higher on the scale the greater difference, each point essentially doubling the punishment. The similarity in the amount of the discounts in light of the exponential nature of the scale seems to confirm that people tend to think in punishment differences in such exponential terms. ${ }^{36}$ The unintended result discount was much larger than the others, suggesting that the absence of intention was a more powerful discount than the other sources of discount presented in the scenarios.

To test the effectiveness of the 'discounting' system as a model for our subjects responses, we compared the actual results against the results that would be generated by a system that used only our hypothesized discounting system. For example, in a very rough approximation, one could assign each discount a value of 1.5 points on the liability scale (representing a point somewhere between 1 and 2 , as four of the five discounts seem to fall). Applying this value to the scenario formulae given in Table III, column 3, the results are represented by the line labeled '1.5 grade' in Figure 1.

\footnotetext{
${ }^{36}$ For a discussion of the tendency of people to think in terms of exponential penalty amounts, see R.E. Harlow, J.M. Darley, and P.H. Robinson, 'The Severity of Intermediate Penal Sanctions: A Psychophysical Scaling Approach for Obtaining Community Perceptions' 11 foumal of Quantitative Criminology 71-95 (1995).
} 


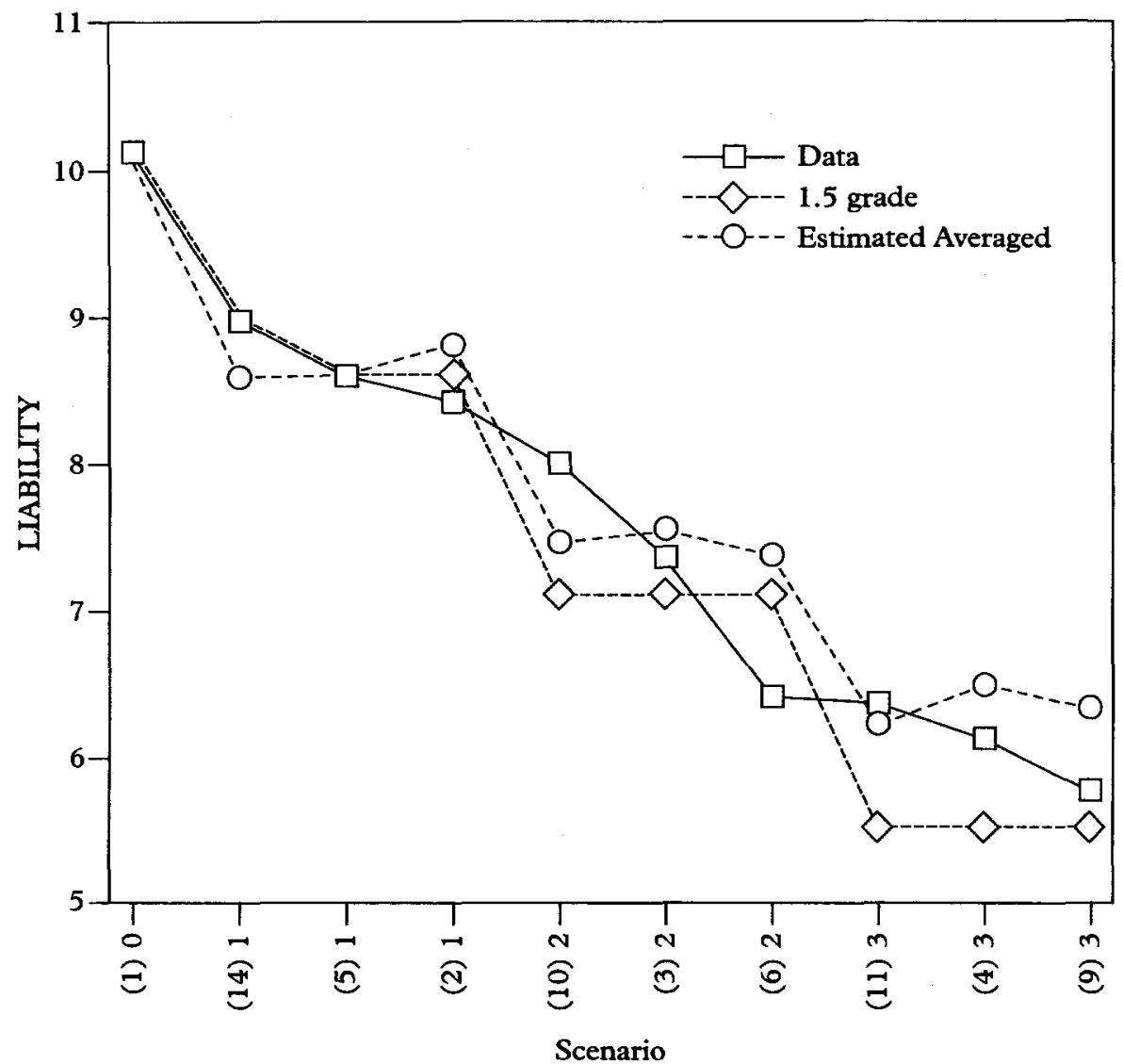

FIGURE 1. Discounting models for murder cases.

For a slightly more accurate model, we used the single discount estimates developed in Table IV. These average values, different for each kind of discount, were then used in the formulae in Table III, column 3. For instance, scenario 11 , as contrasted with scenario 1 , receives both a no-harm and a double incomplete-conduct discount. The average no-harm discount is 1.28; the average incomplete conduct discount is 1.31 , doubled it is 2.62 . We then summed those two discounts, and subtracted the result from the 10.10 liability assignment given to scenario 1 , giving a predicted liability of 6.20. (The actual liability given by subjects for the scenario was 6.29.) The results of this process, done for all of the scenarios, are shown by the line labeled 'estimated averaged' in Figure 1.

There are several results to notice from this figure. Initially, puzzlingly, even for the model that estimated each discount separately, there is occasionally a noticeable difference in the liability assigned by it to the scenarios with single 
discounts from the liability actually given by the subjects. This is so because the modeled liabilities are sometimes averaged ones, and as we noted above, they differ from the specific ones assigned to specific instances. So, for instance, the estimated average model prediction for scenario 2 somewhat underestimates the actual discount the subjects gave that case.

Overall, we are struck by the degree to which either version of the additive discount model does a good job of modeling the data. Again, the study was not designed to derive a model for the psychological processes the subjects used to generate their liability judgments. We would argue that the discounting model receives sufficient support from our after-the-fact modeling to warrant testing in future research. Its central notion, that liabilities are generated by considering crime prototypes, and the number of differences between the actual case and the prototype, represented in terms of five discounting principles, seems intriguing. If validated, it is a formulation that could be used to generate a viable and conceptually understandable set of sentencing guidelines. ${ }^{37}$

\section{Conclusion}

\section{A. Limitations of the Study}

To begin, we ought to acknowledge the limits of the generalizations that can be drawn from any one study, and particularly the one study we did. Four potential limitations are important to note. First, while we wish our results to be about different liability views toward crimes in general, we presented our subjects with scenarios about mainly, but not solely, one crime, the crime of murder. Of course, we made that choice deliberately; murder is the crime that is likely to attract the most severe liability judgments from subjects, and we wished to give room for large changes in liability judgments if the circumstantial variations were perceived by subjects as major mitigations. And we note that we found these major mitigations; some subjects judged the protagonist 'not guilty' in some scenarios and imposed life sentences in other scenarios. Still, the patterning of judgments in which the core crime is other than murder needs to be explored.

Second, and closely related to the first point, when we created, for instance, the scenario for the factually impossible attempt case, we created only one such scenario, but one can see that there can be a family of such cases. Again, and of course, we created the one we did because it was the one we found the most relevant. The perpetrator shot at a wax dummy made to look like the intended victim because the police were concerned about possible attacks on the intended

\footnotetext{
37 This discounting conceptualization is presently part of the framework of the United States Sentencing Commission Guidelines. The basic structure of the guidelines is for each offence or suboffence to have a base punishment 'level', which is then adjusted according to the presence of various factors. Thus, an actor's role in the offence as a minor accomplice reduces the actor's guideline sentence by one or more levels from the offence's base level. See United States Sentencing Commission Guidelines s. 3B1.2. Similarly, an inchoate offence is reduced in level from that of the substantive offence. Ibid at s. 2 X1.1. One of us served as one of the original Commissioners who created the structure of the current guidelines.
} 
victim. We wanted to compare this scenario to others in which the actor similarly intended harm and acted to cause it. Certainly, a very different liability assignment would be given to an impossible attempt case in which the perpetrator made a wax dummy of the intended victim and shot it, thinking that somehow this would kill the victim $!{ }^{38}$ Further research, driven by theoretical considerations for varying the exact content of the scenarios, will extend the generalizations that can be made and certainly qualify them in interesting ways.

Third, we employed what is called a within-subjects research design; each subject rated every scenario. In this sort of design, the subjects can become aware of the theoretical issues that generated the differences among the scenarios. We were careful to instruct the subjects that we did not always expect differences between stories to produce differences between their liability judgments, and the reader will recall that subjects did not always treat different scenarios differently; subjects sometimes rated two scenarios as deserving identical liabilities. Still, it is possible that subjects who are alerted to a particular distinction then decide the distinction is important, but would not have found it important without being alerted to it. Future research, using designs in which a single subject responds to a single case, or a limited number of cases, can investigate this latter possibility. For this first exploration of the topic, we judged the advantages of the within-subjects design, and particularly its unparalleled ability to detect the pattern of judgments given by each individual subject, great enough to make its use appropriate.

Fourth, one can raise concerns about the degree to which our sample of subjects does a good job of standing in for the vast population of citizens whose views are relevant to the debate among the issues that we discuss. But the question here is different from the standard questions one asks about samples and populations. In the standard survey, one wishes to generalize about, for instance, what percentage of the population will assign the death penalty to the perpetrator of the murder described. To establish that percentage accurately, large and carefully stratified samples are necessary. But that is not the sort of generalization we wish to draw. We are instead concerned with the patterning of the different liability assignments made by each individual, and the similarity of the resulting pattern across individuals.

We actually have evidence about both sorts of differences among our subjects, because we had two different sorts of people who responded to our scenarios: students and jury-qualified residents of the town. A difference of the first sort was actually found; students tended to assign slightly more lenient punishments than did citizens. But we did not find a difference of the second sort; the pattern of differences in the liability assignments did not differ between students and citizens. This possibility of analysing patterns is provided by the within-subjects character of the experimental design, and represents a strength of that design. Again, future research will search for important differences in patterning among

\footnotetext{
38 This, among other things, is what is demonstrated in the Finkel et al. research, above n. 31 .
} 
broad samples of subjects, perhaps following up on the discovery of what seemed to be a small but interesting group of people who gave strong objectivist responses throughout and another group that gave subjectivist responses throughout.

\section{B. Implications for Existing Criminal Law}

If our characterization of present lay judgements is correct, and if we are correct in arguing, as we will argue in a moment, that the criminal law ought to mirror the shared intuitions of justice of the community, then both common law rules and modern criminal codes are flawed in that they deviate from our subjects' intuitions. First, the results suggest that the common law doctrines no longer reflect community views, if they ever did. Most importantly, the doctrines that define the minimum requirements of liability at common law draw that liability too narrowly, excluding from liability a variety of actors who today's lay persons see as deserving of criminal liability. The actor whose attempt conduct falls short of 'dangerous proximity', the actor whose criminal agreement is only 'unilateral' because, for example, he or she conspires with an undercover agent, and the actor who mistakenly believes that he or she has committed an offence, because of a mistake as to an existing circumstance, such as a belief that the talcum powder was drugs, all would get a complete defence at common law, but our subjects thought that some liability and punishment was appropriate. ${ }^{39}$

On the other hand, our results suggest that modern codes also miss the mark on important issues. Modern codes generally do a good job in determining the cases in which to assign liability, but fail to acknowledge the importance of many factors that lay persons today think important in determining the amount of punishment deserved. In particular, modern codes sometimes fail to adjust offence grade according to whether the offence harm actually occurs, how far the actor's inchoate conduct has proceeded towards the completed offence, whether the offender was only an accomplice rather than a perpetrator, and whether the offence contemplated by the actor was possible for him or her to commit actually, when our subjects clearly would. ${ }^{40}$

It may well be that individual judges, who may share community intuitions, will use their sentencing discretion to override the grading distinctions of the code and impose a sentence that reflects the community's view of criminality. But this, we think, is no proper solution to the problem of improper code grading for several reasons. First, many sentencing judges may not share the intuitions of the community. ${ }^{41}$ Spending one's days watching a parade of criminals appear for sentencing may well alter one's views of proper punishment to be imposed. Second, even if all judges did share the community's objectivist view of grading, the availability of sentencing discretion creates other serious problems. It is out

${ }^{39}$ See, eg Table II, col. 2, rows 9,11 , and 13 , respectively.

40 See, eg Table II, col. 2 , rows $2,3,5$, and 10 , respectively.

41 Research has demonstrated that sentencing judges hold sentencing-relevant attitudes that differ considerably from other segments of the population. See John Hogarth, Sentencing as a Human Process (1971) at $138-48$. Further, these attitudes predict different patterns of criminal sentencing. Ibid at 148-59. 
of recognition of these problems that the USA is presently in the midst of a wave of sentencing reform manifested primarily in the introduction of sentencing guidelines that reduce judicial discretion.

The press for sentencing guidelines comes from several concerns. Perhaps most importantly, unguided sentencing discretion is likely to generate disparate sentences in similar cases. Different judges have different sentencing philosophies. Some may think general deterrence the most important goal to pursue in a case; others may think rehabilitation the most important goal in an identical case. Still others may think the potential for future offences the most important factor in the same case; others still may think that the punishment deserved for this offence is central in determining the sentence. Other judges may look at the same facts and conclude that some combination of these factors and goals is the best criterion for determining the sentence. Without commitment to a single sentencing theory for a particular kind of case, it seems hard to see how the sentences of different judges could be similar. ${ }^{42} \mathrm{~A}$ further concern about unguided sentencing discretion is the potential for abuse of that discretion, including abuse by the use of improper factors or by conscious or subconscious expression of racial, religious, gender, or other bias.

The trend in modern code drafting, evidenced in the Model Penal Code, is to move toward a subjectivist view of both minimal requirements and grading. These two tendencies, taken together, achieve a sentencing philosophy that is simple to apply, but rather draconian in effect, and quite strongly in conflict with the sentencing patterns shown by our subjects. Our subjects did not treat cases of an externalized intent to commit a crime as equivalent in liability to cases in which the commission of that crime was completed. Instead they were influenced in their liability. judgments by variations in the objective circumstances surrounding the crime: the extent of the actor's causal contribution, how close to completion of the offence the actor came, and the occurrence of harm.

This means that a jurisdiction that moves toward the subjectivist sentencing philosophy of the Model Penal Code is a jurisdiction that moves away from a legal code that embodies the moral intuitions of its citizens. This does not seem to us to be a very wise move to make, for three related reasons. First, for those who think that just deserts represents the preferred mode of distributing criminal liability, the intuitions of the community have a considerable claim to be considered when codes are adopted, and without evidence such as we have generated, any code adopted is unable to give standing to these community intuitions. The code drafters often refer to their speculations about community moral intuitions, indicating that they do think them relevant, and often get them wrong.

Second, as we have argued more fully elsewhere, there is a utilitarian argument for having legal codes that in the main model community intuitions. Where the

\footnotetext{
${ }^{42}$ For a further discussion of the point, see Paul $\mathrm{H}$. Robinson, 'Hybrid Principles for the Distribution of Criminal Sanctions' 82 Northrvestern University Law Review $19-42$ (1987).
} 
criminal law commands the respect of the community it governs, the law's moral credibility itself provides a reason for law abidingness. ${ }^{43}$

Third, as other studies have demonstrated recently, people tend to assume that legal codes conform to their moral intuitions. ${ }^{44}$ This is not a surprising result if one asks what information people have available for inferring the content of codes; they have very little information other than their own intuitions: very little information is made public about the content of criminal codes, and very little attempt is made by code drafters to educate the public about code content. If the codes are in fact far distant from the moral judgments that people use to intuit the content of criminal codes, then people will be seriously confused about the actual content of the codes. This means that a counterintuitive law, unpublicized, fails to serve its $e x$ ante function. It does not provide a clear guide according to which people can govern their conduct in the future. ${ }^{45}$

Earlier, we noted, and supported, a trend towards articulated sentencing rules. As is now clear, we argue that, as sentencing rules become more articulated and less discretionary, it becomes more important for those rules to reflect the objectivist grading intuitions of the community. Sentencing guidelines that embody the subjectivist views of grading typical of many modern criminal codes-such as provisions setting the grade of inchoate conduct as the same grade as that for the substantive offence-would generate sentences likely to undercut the criminal justice system's moral credibility with the public. We support the need for more articulated sentencing criteria, but that improvement increases the need to ensure that the system's rules more accurately reflect the community's views than they have in the past.

To sum up our argument: for all of the reasons that we have detailed, we cannot yet assume that our results' pattern is a perfect representation of community sentiments, although we would be surprised to discover that it was seriously deviant from them. But assuming that our results hold in future research, for all of the reasons we just presented, we advocate adopting a criminal code that mirrors them; we advocate adopting a criminal code that matches the moral intuitions of the community it governs. That entails adopting a criminal code that reflects the subjectivist views of criminality in the definition of minimum requirements for a crime and the objectivist views of criminality in the assignments of grading liability levels. Such a community-standards-based code would be a consistent and coherent one, and one that we think would increase the system's reputation for doing justice, which in turn eventually would serve to reduce crime.

\footnotetext{
${ }^{43}$ Paul H. Robinson and John M. Darley, 'The Utility of Desert' 91 Northwestern University Law Review (1997) 453; Tom Tyler, Why People Obey the Law (1990).

${ }_{44}$ See, eg J.M. Darley, C.A. Sanderson, and P.S. LaMantia, 'Community Standards for Defining Attempt' 39 American Behavioral Scientist 405-20 (1996).

${ }^{45}$ For a discussion of the criminal law's $e x$ ante rule articulation function, see Paul $\mathrm{H}$. Robinson, 'Rules of Conduct and Principles of Adjudication' 57 U Chi L Rev 729 at 730-3 (1990).
} 


\section{Appendix: The Scenarios}

Each scenario is based on the actions of John, who is a 25 -year-old man. During his teenage years, his father, a famously ambitious businessman, rapidly accumulated a great deal of money. The criminal justice system, after several investigations, prosecuted and eventually convicted John's father for income tax evasion.

1. John is angry with prosecutor Paul for Paul's vigorous prosecution of John's father for income tax evasion. John feels the prosecution has ruined both his father's life and his own, and is intent on taking revenge. John buys an easily concealed gun, planning to confront and kill Paul in the parking lot of his office. As prosecutor Paul approaches his car in the parking lot of his office, John, standing several yards away, shoots and kills him.

2. John is angry with prosecutor Paul for Paul's vigorous prosecution of John's father for income tax evasion. John feels the prosecution has ruined both his father's life and his own, and is intent on taking revenge. John buys an easily concealed gun, planning to confront and kill Paul in the parking lot of his office. As prosecutor Paul approaches his car in the parking lot of his office, John, standing several yards away, shoots at him but misses. The sound of the gunfire draws security guards, who arrest John before he can get another shot at Paul.

3. John is angry with prosecutor Paul for Paul's vigorous prosecution of John's father for income tax evasion. John feels the prosecution has ruined both his father's life and his own, and is intent on taking revenge. He buys an easily concealed gun, planning to confront and kill Paul in the parking lot of his office. As prosecutor Paul approaches his car, John, standing several yards away, aims at him intending to kill him. Before he can pull the trigger, however, an astute security guard grabs the gun and arrests John.

4. John is angry with prosecutor Paul for Paul's vigorous prosecution of John's father for income tax evasion. John feels the prosecution has ruined both his father's life and his own, and is intent on taking revenge. He searches for another person to help him to kill Paul and finds an ex-convict who is also angry at Paul. John suggests to him that they obtain a gun, confront Paul in the parking lot of his office, and use the gun to kill Paul. The ex-convict agrees. Their planning is overheard and reported to police. They are stopped by the police and arrested on their way to obtain the gun.

5. John is angry with prosecutor Paul for Paul's vigorous prosecution of John's father for income tax evasion. John feels the prosecution has ruined both his father's life and his own, and is intent on taking revenge. Before he can act, however, John hears that his brother is planning to confront prosecutor Paul in the parking lot of his office. John decides that he will find a gun and bring it to his brother at the parking lot, in the hope that his brother will use it to shoot 
Paul. He arrives just in time to see his brother hiding, waiting for Paul. He gives his brother the gun. His brother uses it to shoot Paul dead. The sound of the gunfire draws security guards, who arrest John and his brother.

6. John is angry with prosecutor Paul for Paul's vigorous prosecution of John's father for income tax evasion. John feels the prosecution has ruined both his father's life and his own, and is intent on taking revenge. Before he can act, however, John hears that his brother is planning to confront prosecutor Paul in the parking lot of his office. John decides that he will find a gun and bring it to his brother at the parking lot, in the hope that his brother will use it to shoot Paul. He arrives just in time to see his brother hiding, waiting for Paul. Before he can give his brother the gun, his brother draws a gun from his own coat and shoots Paul dead. The sound of the gunfire draws security guards, who arrest John and his brother.

7. John is angry with prosecutor Paul for Paul's vigorous prosecution of John's father for income tax evasion. John feels the prosecution has ruined both his father's life and his own, and is intent on taking revenge. John buys an easily concealed gun, planning to confront and kill Paul in the parking lot of his office. As prosecutor Paul approaches his car in the parking lot of his office, John, standing several yards away, shoots at Paul with the intention of missing but scaring him, which he does. Unfortunately, the shot ricochets off a car and strikes and kills a woman nearby. The sound of the gunfire draws security guards, who arrest John.

8. John is angry with prosecutor Paul for Paul's vigorous prosecution of John's father for income tax evasion. John feels the prosecution has ruined both his father's life and his own, and is intent on taking revenge. John buys an easily concealed gun, planning to confront and kill Paul in the parking lot of his office. As prosecutor Paul approaches his car in the parking lot of his office, John, standing several yards away, shoots at Paul with the intention of missing but scaring him, which he does. The sound of the gunfire draws security guards, who arrest John.

9. John is angry with prosecutor Paul for Paul's vigorous prosecution of John's father for income tax evasion. John feels the prosecution has ruined both his father's life and his own, and is intent on taking revenge. He plans to buy an easily concealed gun and to confront prosecutor Paul in the parking lot of his office, where he will shoot him dead. He leaves a note to his brother describing the details of his plan, but the note is unexpectedly found and read by another person who notifies police. The police find John coming out of the gun store mentioned in the note, carrying the gun described in the note as the gun he planned to buy.

10. John is angry with prosecutor Paul for Paul's vigorous prosecution of Tohn's father for income tax evasion. John feels the prosecution has ruined both 
his father's life and his own, and is intent on taking revenge. He buys a gun and approaches Paul as he sits in his car in the parking lot of his office. Standing several yards away, John shoots and kills him, or so he thinks. The police immediately arrest John. It turns out that the police had feared such an attack and had placed a life-like dummy in the driver's seat of Paul's car to serve as a diversion. The police had Paul exit on the other side of the building and drove him home under guard.

11. John is angry with prosecutor Paul for Paul's vigorous prosecution of John's father for income tax evasion. John feels the prosecution has ruined both his father's life and his own, and is intent on taking revenge. He searches for another person to help him to kill Paul and finds an ex-convict who also is angry at Paul. John suggests to him that they obtain a gun, confront Paul in the parking lot of his office, and use the gun to kill Paul. The ex-convict agrees. They are stopped by police on their way to obtain the gun. It turns out that the 'exconvict' is an undercover police agent, who also reported John's plan to the police.

12. John decides to make a lot of money quickly by illegally smuggling cocaine into the USA. He buys two kilos of cocaine during a trip to Columbia, intending to sell it to dealers in New York. At customs in New York, however, his cache of drugs is discovered, and he confesses his plan to police.

13. John decides to make a lot of money quickly by illegally smuggling cocaine into the USA. He buys two kilos of cocaine during a trip to Columbia, intending to sell it to dealers in New York. At customs in New York, however, his cache of drugs is discovered, and he confesses his plan to police. To his surprise, when the seized powder is tested, it is discovered that it is only talcum powder; he had been tricked by his sellers in Columbia.

14. John is angry with prosecutor Paul for Paul's vigorous prosecution of John's father for income tax evasion. John feels the prosecution has ruined both his father's life and his own, and is intent on taking revenge. John buys an easily concealed gun, planning to confront and kill Paul in the parking lot of his office. $\mathrm{He}$ arrives just in time to see his brother hiding waiting for Paul. He gives his brother the gun. His brother uses it to shoot Paul dead. The sound of the gunfire draws security guards, who arrest John and his brother. Only later does John learn that Paul, apparently angry at insults from John's brother, had attacked his brother with a knife and was about ready to attack him again. His brother's shooting of Paul is held to be lawful self-defence. 